\title{
A complete etymology-based hundred wordlist of Semitic updated: Items 55-74
}

\begin{abstract}
The paper represents the third part of the author's etymological analysis of the Swadesh wordlist for Semitic languages (the first two parts having already appeared in Vols. 3 (2010) and 5 (2011) of the same Journal). Twenty more items are discussed and assigned ProtoSemitic reconstructions, with strong additional emphasis on suggested Afrasian (AfroAsiatic) cognates.
\end{abstract}

Keywords: Semitic, Afrasian (Afro-Asiatic), etymology, glottochronology, lexicostatistics.

The present study contains the analysis of the third portion of a 100-wordlist of Semitic. It is a follow-up to the author's second attempt at compiling a complete Swadesh wordlist for most Semitic languages that would fully represent all the branches, groups and subgroups of this linguistic family and provide etymological background for every item wherever available. It is another step toward figuring out the taxonomy and building a detailed and comprehensive genetic tree of said family and, eventually, of the Afrasian (Afroasiatic) macro-family with all its branches on a lexicostatistical/glottochronological basis.

Several similar attempts, including those by the author (Mil. 2000, Mil. 2004, Mil. 2007, Mil. 2008, Mil. 2010, and Mil. 2011), have been undertaken since M. Swadesh introduced his method of glottochronology (Sw. 1952 and Sw. 1955). In this paper, as well as in my previous studies in genetic classification, I have relied on Sergei Starostin's glottochronological method (v. Star.) which is a radically improved and further elaborated version of Swadesh's method.

The present portion includes twenty more items out of the 100-wordlist. I hope to fill all the Afrasian gaps in the first two portions as a supplement to the last (forthcoming) portion. It should be stressed once more that my aim is not to give complete data from all the nonSemitic Afrasian languages for all the items (i.e. not the complete etymological entries), but only to present available data demonstrating the Afrasian origin of all Semitic words involved, inter alia, to eliminate or reduce the possibility of the latter items to have been borrowed. Compared with the same 12 items (Nos. 55-66) of the list included in my previous paper (Mil. 2008), these ones are updated, corrected in some points, and some more reliable etymologies are suggested.

This study was carried out within the frames of the project No. 09-06-00153 Featuring early Neolithic man and society in the Near East by the reconstructed common Afrasian lexicon after the Afrasian database, supported by the Russian Foundation for Sciences. My gratitudes also go to my colleagues and collaborators in different projects: Prof. O. Stolbova (with whom we collaborate on the Afrasian Database within the "Evolution of Human Languages" project, from where I draw most of the data) and Drs. L. Kogan and G. Starostin for consultations and discussions. I am also indebted to Drs. A. Nemirovskaya for a commented 100-word list of Palestinian Judaic Aramaic; M.Bulakh for obtaining for me a 100-word list from a Tigre speaker; and to L. Kogan for sharing with me the Soqotri list (namely, of the Bedouin dialect of Darho in the central part 
of Socotra) compiled during his recent expedition to Socotra in November 2010, which made it possible for me to check a few items and cancel several synonyms that, for lack of more precise data, I had to treat on par with the corresponding main term in my previous list.

The list below is based on the following main sources (not referred to in the text except for special cases): Akk. - CAD and AHw; Ugr. - DUL; Hbr. and Bib. - HALOT; Pho. - Tomb.; Pal. - Sok. JP; Syr. - Brock. and Sok. Syr.; Mnd. - DM; Urm. - Tser. and Sarg.; Qur. - Pen. and BK; Leb., Mlt. - native speakers, Mec. - Sat.; Sab. - SD; Gez. - LGz; Tna. - native speakers and Kane T; Tgr. - a native speaker and LH; Amh. - native speakers, Baet. and Kane A; Arg. - LArg; Gaf. - LGaf; Sod. and Cha. - native speakers and LGur; Har. - a native speaker and LHar; Wol. - LGur; Hrs. - a native speaker and JH; Mhr. - native speakers, JM and Nak.; Jib. - native speakers, JJ and Nak.; Soq. - data collected by L. Kogan and LS.

\section{The Data.}

The data consist of items 55-74 of Swadesh's 100-wordlist of 28 Semitic languages, representing all groups within the family. Each item unites all the synonyms that are different in origin, i.e. form different sub-entries within the same entry, each of which is preceded by its own number (in round brackets). Each sub-entry, in its turn, consists of one or several cognate lexemes divided by a semicolon; the etymological comments including a Sem. protoform follow after a double slash; non-Semitic Afrasian parallels and a suggested Afrasian proto-form follow after the symbol $\square$. Note that for cases when the choice of only one representative lexeme in the same language is too difficult, ${ }^{1}$ Starostin's procedure allows for several synonyms in the same language to be scored; in this case, synonyms from the same language would be present in two or more entries. Within each item there may occur two kinds of cases which are not scored at all - borrowings and lack of a corresponding term in the available sources; such cases form a separate section within the item, preceded by the symbol $\diamond$. Each item is completed (after the symbol $\rightarrow$ ) with its Semitic proto-form(s) if any on the deepest level of reconstruction available (Proto-Semitic, Common West and South Semitic, etc.) in accordance with my classification of Semitic.

The following dates (some of them averaged, approximate or fairly conventional, some chosen after much hesitation and discussions with specialists in individual languages, and still liable to changes before a final scoring) have been attributed to individual languages: Akkadian, 1450 B.C.E.; Ugaritic, 1350 B.C.E.; Hebrew, 650 B.C.E.; Phoenician 850 B.C.E.; Biblical Aramaic, 200 B.C.E.; Palestinian Judaic, 200 C.E.; Syrian Aramaic, 200 C.E.; Mandaic, 750 C.E.; Urmian Aramaic, 1900; Qur'anic Arabic, 600 C.E.; Lebanese Arabic, 2000; Meccan Arabic, 2000; Maltese Arabic, 2000; Sabaic, 200 B.C.E.; GeYez, 500 C.E.; Tigrai, 2000; Tigre, 2000; Amharic, 2000; Argobba, 2000; Gafat, 1900; Soddo, 2000; Harari, 2000; Wolane, 2000; Chaha, 2000; Harsusi, 2000; Mehri, 2000; Jibbali, 2000; Soqotri, 2000.

\section{Abbreviations of languages, language periods and ancient sources.}

A, Ass. - Assyrian; Afras. - Afrasian (Afroasiatic, Semito-Hamitic); Akk. - Akkadian; Amh. - Amharic; Arb. - Arabic; Arg. - Argobba; Arm. - Aramaic; B - Babylonian, BD Book of the Dead; Brb. - Berber; Bib. - Biblical Aramaic; C. - Central; Cha. - Chaha;

\footnotetext{
${ }^{1}$ Even in cases when making such a choice was possible, I sometimes adduced more than one synonym, unable to resist the temptation of providing more terms with Semitic and/or Afrasian etymology. In the concluding phase of this study, I will do my best to make the selection procedure as strict as possible, and eliminate all superfluous synonyms from the final scoring.
} 
Chad. - Chadic; Clas. - Classical; CT - Coffin Texts; Cush. - Cushitic; Dat - Datinna Arabic; Dem. - Demotic; Dof. - Dofar Arabic; Dyn. - Dynasty; E. - East; Egyp. - Egyptian; ESA - Epigraphic South Arabian; Eth. - Ethiopian; Frah. - Frahang-i-Pahlavik (Aramaic); Gaf. - Gafat; Gez. - Gefez; Gr. - Greek; Gur. - Gurage; Har. - Harari; Hụr - Haḍramawt Arabic; HEC - Highland East Cushitic; Hbr. - Hebrew; Hrs. - Harsusi; Jib. - Jibbali; Jud. - Judaic Aramaic; LL - lexical lists; Leb. - Lebanese Arabic; LEC - Lowland East Cushitic; Mlt. - Maltese Arabic; Mec. - Meccan Arabic; Med. - Medical Texts; met. metathesis; Mhr. - Mehri; MK - Middle Kingdom; Min. - Minean; Mnd. - Mandaic Aramaic; Mod. - Modern; MSA - Modern South Arabian; N - New, N. - North; NE - New Egyptian; NK - New Kingdom; O - Old; OK - Old Kingdom; Omot. - Omotic; Pal. - Palestinian Judaic Aramaic; pB. - postbiblical; Pho. - Phoenician; Pyr. - Pyramid Texts; Qat. Qatabanian; Qur. - Qur'anic Arabic; S - Standard, S. - South; Sab. - Sabaic; Sem. - Semitic; Sod. - Soddo; Soq. - Soqotri; syn. - synonym; Syr. - Syrian Aramaic; Tna. - Tigriñña (= Tigray); Tgr. - Tigre; Ugr. - Ugaritic; Urm. - Urmian Neo-Aramaic; W. - West.; Wol. Wolane, $\mathrm{Y}-$ Young.

\section{Transcription and transliteration. ${ }^{2}$}

$\dot{p}-$ bilabial emphatic voiceless stop; $\underline{b}-$ bilabial emphatic voiced stop; $\underline{b}-$ bilabial voiced spirant; $t$ - dental emphatic voiceless stop; $d$ - dental emphatic voiced stop; $\underline{t}-$ voiceless interdental fricative (in Egyptian, a conventional symbol most likely conveying č); $\underline{d}$ - voiced interdental fricative (in Egyptian, a conventional symbol most likely conveying $\tilde{3}$ ); $c-$ alveolar voiceless affricate [ts]; $3-$ alveolar voiced affricate [dz]; $\check{c}-$ palato-alveolar voiceless affricate [tš]; $\check{z}-$ palato-alveolar voiced affricate [dž]; ș - alveolar emphatic voiceless fricative; $c-$ alveolar emphatic voiceless affricate; $z-$ conventionally stands for what was likely $\underset{d}{d}$, emphatic voiced interdental fricative, or $\underline{t}$, emphatic voiceless interdental fricative; $\check{c}$ - palato-alveolar emphatic affricate; $\hat{s}-$ lateral voiceless fricative (denoted by $\hat{s}_{x}$ in Sem. reconstructed proto-forms); $\hat{c}$ - lateral voiceless affricate; $\hat{s}$ - lateral voiceless emphatic fricative; $\hat{c}$ - lateral voiceless emphatic affricate; $\hat{z}$ - lateral voiced emphatic sibilant (or perhaps affricate); $\hat{z}$ - lateral voiced sibilant; $\bar{g}$ - voiced velar fricative (in Berber); $k$ or $q-$ emphatic velar stop; $q-$ hypothetic velar affricate $\left[\mathrm{k}^{\mathrm{h}}\right]$ (only in reconstructed Afrasian protoforms); $\gamma-$ uvular voiced fricative (Arabic "ghain"); $h-$ uvular voiceless fricative; $\underline{h}-$ presumably velar voiceless fricative (only in Egyptian); $h$ - pharyngeal voiceless fricative; $\varepsilon-$ pharyngeal stop ("ayin"); $h$ - laryngeal voiceless fricative; ? - glottal stop ("aleph", "hamza"); $y$ - palatal resonant; ? and $i$ - conventional transcription symbols accepted in Egyptology.

\section{Conventions for reconstructed protoforms.}

$V$ renders a non-specified vowel, e.g. *bVr- should be read "either *bar-, or *bir-, or *bur-".

$H$ renders a non-specified laryngeal or pharyngeal.

$S, \mathrm{Z}$ render a non-specified sibilant.

/ when separates two symbols means "or", e.g. *2i/abar- should be read "either *2ibar- or *2abar-".

( ) a symbol in round brackets means "with or without this symbol", e.g. * $b a(w) r$ - should be read "*bawr- or *bar-".

means "and" pointing to two or more co-existing proto-forms.

2 I should stress again, as I usually do in my publications, that the vocalism in the reconstructed Semitic and, especially, Afrasian protoforms is ofen conventional and hypothetic. 


\section{MOUNTAIN}

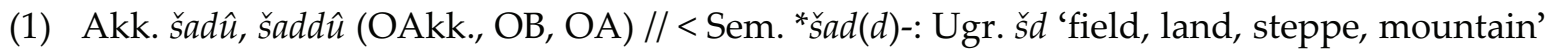
(DUL 807); Arb. sadd- 'montagne' (BK 1 1068).

(2) Ugr. $\gamma r\left(\gamma<{ }^{*} \underline{d}\right)^{3}$; Bib. țūr; Pal. țwr; Syr. țūr-; Mnd. țur-; Urm. țūr-; Sab. z̧wr //< Sem. *țu/ir'flint, rock': Akk. șurru, Hbr. șōr, Arb. zurar-, z̧irr- 'flint', etc.

$\square \quad$ Cf. Brb.: Qabyle i-zra 'flint' (otherwise an Arabism?), Ahaggar a-zoru 'rock' and W. Chad.: Hausa çúrá 'knife or sword without handle', presumably implying Afras. *ç̌ur- 'flint' (ADB).

(3) Hbr. hār; Pho. hr // Only Ugr. hr 'mountain' (DUL 345; not a basic term).

$\square \quad$ There are isolated parallels outside Sem. suggesting Afras. *hawr- (ADB): Brb.: Ahaggar ăhor 'amoncellement des rochers'; W. Chad.: Geruma yuworo 'stone', Zar wur 'mountain'; E. Cush.: Yaaku hérro? '(big) rock'.

(4) Qur. క̌abal-; Leb. žabel; Mec. ̌̌abal, Mhr. gabēl, Jib. gicil // < Sem. *gVbVl- 'mountain; boundary, border': Ugr. gbl 'limit, frontier' and 'summit, mount' (in DUL 293, two "possibly related" different entries; v. Kog. Ug.-Sem. 11), Hbr. gabūl 'mountain; boundary; territory', etc. (HALOT 171), Bațhari gabalēl 'mountain' (JM 113). Whether the MSA forms are genuine or borrowed from Arb. (note lack of the root in Soq.) is hard to decide.

$\square \quad$ Probably < ${ }^{*} g V b$ - Vl- with the $-l$ root extension (v. Mil. RE 115-18) < Afras. * $g a / u b$ - 'mountain' (ADB): Sem. * ${ }^{*} a / i b \varepsilon-($ with the $-\{$ root extension?): Akk. gab?u '(mountain) peak, hill', Ugr. $g b \varepsilon$ 'hill, height, peak', Hbr. gibsā 'hill', Arb. ̌̌ubas- 'little hill town'; (?) E. Chad.: Bidiya gab-ga (partial redupl.) 'mountain'; Cush. N.: Beja gwob 'heap of stones; the ground with little or no vegetation', E.: Afar gubb-i 'high spot in undulating country', LEC: Oromo gubba 'summit', HEC: Burji gubba 'highland', Dullay: Tsamay gupo, Harso gúpo 'mountain', S.: Dahalo guba 'plains' (with a plausible semantic shift: cf. \#6 below). Cf. Egyp. (Pyr.) $g b b$ 'Erdgott; Erde'.

(5) Sab. .r (syn.) // also 'citadel; hill-town' (SD 20). In HALOT 821, compared to Hbr. Sìr, Ugr. Er 'city, town', which is acceptable only if the meaning 'hill-town' is a primary one (this is not very likely since, first, the semantic shift to 'mountain' is rather strange; second, there is nothing pointing to a 'hill-town' in Ugr. and Hbr.; and, third, the Ugr.-Hbr. term is regarded as a Sumerism ibid.); for an alternative etymology cf. Arb. \{usurat- 'sommet (d'une mountagne)' (BK 225).

(6) Gez. dabr; Tgr. däbar // < Sem. *dabr- 'mountain valley, pasture': Hbr. dobär 'pasture', Mnd. dibra 'field' (HALOT 212), Arb. dabr- 'champ, pré' (BK 1 664), Tna. däbri 'mountain' (Kane T 2114; not common, according to my informants).

$\square \quad$ Probably < ${ }^{*} d a b$ - with $-r$ extention (v. Mil. RE 110-15) < Afras. ${ }^{*} d V(m) b$ - 'rock': Sem.: Arb. dabbat-, Tgr. däbb 'sand hill', Tna. dabb 'banc de sable' (DRS 205), Harari dabba 'raised ground' (acc. to LGz < Cush.); E. Chad.: Migama dâmbá 'mountain', Bidiya dòmbà id., dàmbo 'stone'; Cush. N.: Beja dabba, dibba 'mound of earth or sand' (perhaps an Arabism), C.: Bilin dabba 'elevated place; mountain; uninhabited country', Qwara, Kailiña, Kemant daba, Dembea debba 'mountain', Aungi dab 'stone' (Fleming); E.: LEC: Somali dabo 'hill, small mountain', HEC: Sidamo dubbo 'forest, uninhabited place', Yaaku tepu < *deb'stone'; N. Omot. Mao démphêe 'mountain' (ADB; partially ND 497a, App. CDA 102).

(7) Amh. tärara; Arg. tärara // No reliable parallels in Sem.

\footnotetext{
${ }^{3}$ As an alternative etymology suggesting Ugr. $\gamma<$ Sem. ${ }^{*} \gamma$ proposed by De Moor, the words allegedly meaning 'rock', 'woodland' are quoted in DUL 324: Arb. fār-, Syr. Sarō and Akk. èru; while the first one is glossed as 'terrain plat, pays plat, caverne' in BK 2 516, I could not find the latter two with these meanings in corresponding dictionaries.
} 
$\square \quad$ Obviously connected with C. Cush.: Kemant tarārā, E.: Cush.: LEC: Munsiye tarra 'mountain', but the direction of borrowing is unclear. Should perhaps be related, with a semantic shift, to Egyp. (Pyr.) tw? 'to raise, hold up, support, lean on' (if < *twr) and Chad. W.: Pero túrù 'climb', Tangale ture 'jump, wake up, rise', C.: Ga'anda itiri, Gabin, Boka tiri, Hwona ture- $\eta$ 'lift', Zeghwana átiž́a 'above' (ADB).

(8) Har. säri // Zway 'id.', cf. a parallel in Arb. sarw- 'légère élévation de terrain', sarāt- 'hauteurs, partie la plus élevée d'un pays' (unless a semantic shift from id. 'dos' and/or 'milieu' BK 1 1085); less likely a loan, with semantic shift, from Somali seeri 'forest' (LGur 557).

(9) Hrs. kermaym; Mhr. karmaym (syn.) // probably < Sem. * karm-, if so, then meaning something like a 'hill with a vineyard in it': Akk. karmu- 'Ödland(-Hügel)' (AHw 449; 'ruin, ruin heap' in CAD k 218), Ugr. krm, Hbr. käräm, Arb. karm- 'vineyard' (DUL 455; HALOT 498), etc.

$\square \quad$ With a much-discussed parallel in Egyp. (MK) k?m.w 'vineyard', which may belong to a small group of the earliest Canaanisms in Egyp. (cf. also W. Chad.: Hausa kúrmì "wood, forest'); cf. a variant root: Akk. (OA, OB on) karānu (kirānu) 'wine, grapevine, grapes' (CAD $k$ 202) and Egyp. (MK) k? $n-w$ 'vineyard', creating a rather enygmatic tangle (ADB).

It is also possible to compare the MSA root, with a fossilized $-m$ (v. Mil. RE 105-8), with Sem. *kur-: Arb. kürat- 'country, land, town', Sab. kwr 'hill, high-place' < Afras. *kur(-Vm)- (cf. also Sum. kur 'mountain, highland' < Afras.?): Chad. W.: Gerka kir 'hill', C.: Dghwede kwire, Glavda ákura, Musgu kurí 'stone', Logone, Kuseri kur 'mountain', Makari kur 'round rock'; Cush. C. *karVy- (<*karVm-) 'stone': Bilin, Kemant karya, Aungi kárá, etc. (App. CDA 129): E.: LEC: Somali, Rendille kúr 'mountain' (ADB).

(10) Soq. félídehon // Jib. fúdún 'rock, stone' (JJ 51); if joined to Akk. (OAkk. on) padānu, paddānu 'path, way' (CAD p 2), implies Sem. *pad(d)Vn- 'path in the mountains'; cf. also, with metathesis, Arb. fand- 'grande montagne, grande hauteur qui s'étend au loin' (BK 2 637).

$\square \quad$ Note a curious triconsonantal parallel in W. Chad.: Tangale pandi, Mangas nadap (another met.?), Kir ladàà (<*nadap?) 'path'.

$\diamond \quad$ Mlt. montaña < Italian montagna; Tna. Zamba < C. Cush. (cf. Bilin ambáa, Khamir 2aba, etc.); Sod. gara < E. Cush (Oromo gaára, Sidamo gaaro, etc., v. LGur 288); Cha. $k^{w} \ddot{a} t o<$ E. Cush. (Qabenna, Alaba kôtá-ta, v. LGur 506). No term in Gaf. and Wol.

$\rightarrow$ No common Semitic (or, if MSA terms are inherited, Common West and South Semitic * $g V b V l-\# 4)$.

\section{MOUTH}

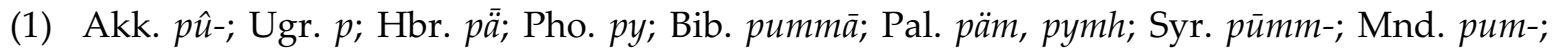
Urm. pūm-; Qur. fam- (also fü/uh- and fuw-); Mec. famm; Gez. 2af; Tna. 2af; Tgr. 2af; Amh. 2af; Arg. af; Sod. af; Har. af; Wol. af; Cha. af // < Sem. *(2a-)pay/w(-m)- 'mouth' (cf. SED I No. 233). The decision to include the Eth. forms into the Sem. root was taken with much hesitation, as they formally coincide with a common Cush. term for 'mouth', the grounds for regarding them as related to or borrowed from Cushitic being nearly equal, cf. below.

$\square$ Anyway, < Proto-Afras. *(2a-)pay/w-'mouth': Brb: Shilh, Senhaja, Qabyle fa, Rif fa, afa, Mzab fafa 'to yawn' (N-Z 515); Chad. W. * $p V w$ - 'mouth': Angas po, pwo, Chip pwà, Tangale $p$ - $k$, Boghom piap, pyòk, Fyer, Bokkos fo, etc. (and very likely Hausa áfà 'throw into the

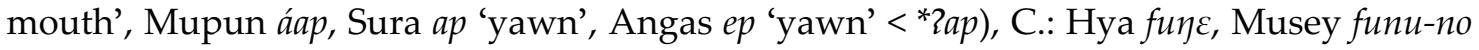
(and vun in several languages, likely <*fun- <*fu-n-); Cush. N.: Beja yaf, C.: Bilin (pl.) afaf, Khamir af, E. *2af- 'mouth': Saho, Afar af, LEC: Somali áf, Rendille af, Dasenech ¿àfù, Oromo áfaa-ni, Konso áfaa, HEC: Darasa afazo, Sidamo, Kambatta afoo, Burji afée, S. *zaf-: Iraqw, Burunge, Alagwa afa, Asa afo-k, Qwadza afu-ko, Dahalo 2afo; S. Omot. *2Vpp/ff- 
'mouth' (seems an inherited root rather than borrowed from Cush.): Dime 2appo, Ari aaffa, Karo 2apo, Banna aapo, Hamar a(a)fo, ap-, Ongota Ziifa (ADB).

(2) Leb. halar; Mlt. halza // < Sem. *halk.(-um)- 'Adam's apple, throat': Akk. *a/elī/āku in lik (lak, alik, elak) pî 'palate' (lit. "the l. of the mouth”), Arb. halk- 'gosier, gorge', halkūm- 'gorge', Gez. halk 'throat, gullet, palate', Amh. allakt 'depression at the base of the neck directly below the Adam's apple', Mhr. halkamūt 'Adam's apple', etc. (v. SED I No. 117).

$\square \quad$ < Afras. * (ha-)lVk.(-um)- 'throat and upper part of neck' (ADB): Cush. C.: Khamtanga kálma, Khamta k/kälma (met.) 'neck', E.: LEC *luk/k(-um)- 'neck': Somali lukun, pl. lukum-mo, Arbore lúko (<*luk- or *luk-), Elmolo lúku (<*luk-), Konso holma (<*kVlm-), Oromo lukum 'chew, munch, eat without opening the mouth', S.: Dahalo laka 'area under chin'; S. Omot.: Banna lukum-, Ongota lufoma 'neck' .

(3) Gaf. samotä // In LGaf 231, qualified as a loanword from E. Cush. Gudella súme; a possible origin from samä 'embrasser' is admitted as an alternative (neither assumption is very convincing); cf. Gez. saß/2ama, Tna. säßamä, Amh. samä, etc. 'to kiss', compared in LGz 481 with Arb. (Yemen) saSam 'kiss', evidently implying the meaning 'kisser' for the Gafat form.

(4) Hrs. hah; Mhr. hōh; Jib. hoh; Soq. he // < Sem. *haw- *hawh- 'hole, aperture': Hrs. howwēt 'tunnel', Mhr. hōh 'mouth; entrance, opening' (JM 454), ḩow $\bar{u}(t)$ 'to have a space left uncovered' (ibid.), Hbr. hăâ̄h-ìm (pl.) 'hole, crevice' (HALOT 296), Arb. ḩwy 'ê. vide’ (BK 1 651), hawhat- 'lucarne dans un mur; petite fenêtre; anus' (ibid. 644), Sab. hwwh 'passageway, corridor' (SD 64), Gez. hohot 'door, doorway, etc.' (LGz 260).

$\square \quad$ Cf. debatable external parallels, pointing, if valid, to Afras. *qaw/2- 'hole': Egyp. (Gr.) h-t 'pit'; Chad. W.: Pero káà 'hole in a stone for mashing grains, beans', C.: Bura ku 'hole in the ground', Bachama kwa 'vine door (hole hut)', Bana kázú 'hole without an outlet', etc. (St. 2011 \#179a), Chibak kaw, Margi kàro 'hole', E.: Kera ku, Kwang kuh, kuu 'mouth' (not in St. 2011); N. Omot.: Kafa koko 'mouth' (ADB).

$\rightarrow$ Common North and West Semitic ${ }^{*}(2 a-) p a y / w(-m)-(\# 1)$.

57. NAME

(1) Akk. šumu; Ugr. šm; Hbr. šēm; Pho. šm; Bib. šum; Pal. šēm, šwm; Syr. šam; Mnd. šum-; Urm. šimm-; Qur. 2ism-; Leb. Zasam; Mec. ism; Mlt. isem; Sab. s1 m; Gez. sam; Tna. sam; Tgr. sam; Amh. səm; Arg. səm; Gaf. səmwä; Sod. səm; Har. sum; Wol. sum; Cha. šam; Hrs. hem; Mhr. ham; Jib. šum; Soq. šem // < Sem. *(2i-)šim-.

$\square$ < Afras. ${ }^{*}(2 i-)$ sim- 'name' (ADB): Brb. ${ }^{*}(H)$ ism- (borrowing from Arabic is unlikely, since the term is attested all over the Berber-speaking area, but cannot be completely ruled out); Chad. W. *(2V-)si/um-: Hausa súná, Sura súm, Kirfi šimí, Pa'a sim, sun, Mangas wusim, Boghom yìsím, Kir wùsum, Tala sum, Kulere Zasím, etc., C. * ŝim- (with a secondary lateralization): Gabin ŝ̀me, Mbara ŝim, Gudu lim, Logone sémī, Zime-Batna sém, etc., E. * $s V m$-: Somrai súmí, Kera sám, Dangla sĩn, Mokilko sùmá, etc.; Cush. *sim- (borrowing from Eth. is less probable, but cannot be excluded): N.: Beja sim, sum, C.: Bilin, Khamir, Kemant ša ${ }^{w}$ (hardly a loan), Aungi sam (likely an Amharism), E.: HEC: Darasa, Hadiya summa, Sidamo, Kambatta surma (cf. also LEC: Oromo sima 'to welcome'); N. Omot. *sum-t- 'name' (in view of *t less likely a loan from Eth.): Wolaita sunta, Basketo sumsa, Koyra súunci, Chara sumá, Gimirra (She) sum, Bworo šuuca, Dizi (Maji) simu, etc. Probably related is Egyp. (MK) smy 'berichten, anzeigen' (with a semantic shift 'tell the name' > 'report, inform'?).

$\rightarrow$ Common Semitic *(2i-)šim-.

${ }^{4}$ The hypothetical ${ }^{*} q$ (standing for a presumed Afras. affricate ${ }^{*} k^{h}$ ) is expected to yield ${ }^{*} h$ in Sem. and Egyp. and ${ }^{*} k$ in other Afras. branches. 
58. NECK

(1) Akk. kišāadu; Gez. kasād; Tna. kasad // < Sem. *ki(n)šād- 'neck, top of shoulder' (SED I No. 147).

(2) Hbr. șawwā(2)r; Bib. șawwąr; Pal. șwwr; Syr. șawr-; Mnd. șawr- // < Sem. *șawzar-: Arb. șawr'side of the neck', etc. (v. SED I No. 258).

(3) Qur. Sunk-; Mlt. (gh)ona? // < Sem. *VVnk- 'neck': Jud. Sunk- 'neck, throat', Gez. Sanaka 'to carry around the neck', etc. (SED I No. 15).

(4) Leb. razabi; Mec. ragaba // Class. Arb. rakb- 'cou, nuque' (BK 1 905). No visible cognates in Sem.

$\square \quad$ Cf., with metathesis, possible parallels in Egyp. (NE) bik (neck or throat determinative) 'gorge (?)' (if < *brk, v. EDE II 94) and Brb.: Rif a-berkuk 'bosse, tumeur' (N-Z 117).

(5) Tgr. sagad // < sägda 'prostrate oneself' (implying an exotic semantic shift "prostrate" > "to bow down one's neck" > "neck") < Sem. *sgd 'prostrate' (LGz 490)?

(6) Amh. angät; Arg. angäd, hangät; Gaf. angät; Sod. angät; Har. angät; Wol. angät; Cha. angät // Judging by Arg. hangät, rather < Sem. *hVng(-ar)- than < * $₹ V n g(-a t)-$ 'neck' (as in SED I No. 15 note): Gez. hongat 'goiter' (h-instead of the expected *h- may be purely graphic), Har. hangūr 'throat' (also 'food'), Zway angäro, Wol. angoro, Selti angōro id. (all of these S. Eth. forms are considered Arb. loans in LLw 132), Arb. ḩanžarat-, hִunžūr- 'larynx' (cf. hunň̌ŭd-id.) (SED I No. 15 note).

$\square \quad$ With a clear parallel in Egyp. (18 Dyn.) hngg 'gorge' (cf. also Brb.: Ghadames angar 'pleurer un mort' - a kind of "gorge" singing?).

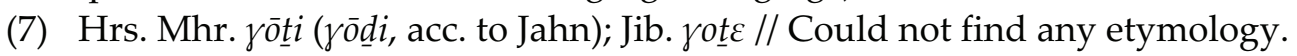

(8) Soq. ḳar // Likely related are Mhr. șārīr 'nape' (SSL 291), with Mhr. ș rendering palatalized ${ }^{*} k$ (cf. in *șawzar- SED I No. 258 note) and Arb. karan (< *karw-) 'dos' (BK 2 730).

$\square$ < Afras. *kawr- '(back of) neck': E. Chad.: Kwang kòrí, Kera kur, Lele kwara 'neck', possibly $<{ }^{*} k$ Vwar- (otherwise < ${ }^{*} k$-ur-); E. Cush.: LEC: Somali qōr 'neck'; Omot. N.: Wolamo ḳōriya, Cancha, Gemu, Dorze kōre, S.: Banna korči $(<* k o r-t-)$ id.

(9) Soq. fakrere (syn.) $)^{5} / /<$ Sem. * pilark-at- *pilakr-at-: Hbr. mapräkät 'neck', Arb. fakrat-, fikrat'vertèbre' (BK 2 619-20), etc. (SED I No. 219).

$\diamond \quad$ Urm. kadāl- is < Arb. kị̂āl- 'derrière de la tête; toupet' (BK 2 697). No term in Ugr., Pho. and Sab.

$\rightarrow$ Common North and West (Eth.) Semitic. *kišād- (\#1).

\section{NEW}

(1) Akk. eššu; Ugr. ḥdț; Hbr. ḥādāš; Pho. ḥdš; Bib. ḥ̆dat; Pal. ḥdt; Syr. ḥadat-; Mnd. hadt-; Urm.

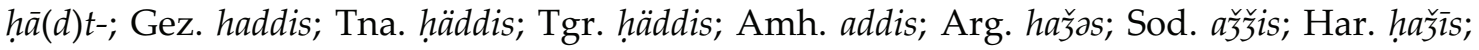
Wol. ǎ̌is // < Sem. *hadiț- (DRS 837).

(2) Qur. క̌adìd-; Leb. ždìd; Mec. ร̌adiyd; Mlt. ̌̌dìd // In Kog. LE 470, reasonably related with Sab. $h$-gdd 'endorse, validate (a decree)' and Qat. $s_{1}-g d d$ 'renew, validate'; compared (with a question mark) with Syr. gaddūd- 'adolescent' in DRS 100, which also seems reasonable, especially in view of another meaning of Arb. ̌̌adìd- - 'jeunesse, jeune âge' (BK 1261$){ }^{6}$

$\square \quad$ Note a curious coincidence with N. Omot.: Yemsa gaddo 'new'.

(3) Sab. $k s_{2} b-m / /$ also $k s_{2} b-n$ 'new construction' < $k s_{2} b$ 'build, construct, make' (SD 108). Clearly connected with Arb. kaš̌i b- 'tout neuf, nouvellement fait' (BK 2 741; seems isolated from

${ }^{5}$ fikeríroh in Kogan MS, given on par with kar as an equiright synonym.

${ }^{6}$ Perhaps from still another meaning of the same Arb. term - 'hereuse, fortuné' (ibid.) < Sem. * gadd- 'fortune, chance' (DRS 100, a different entry), attested in Hbr., Arm. and Eth. (incl. 'augur' in Amh.), with the semantic shift "new" < "future" < "read the future, tell one's fortune" < "fortune". 
other meanings of the verb $k s s b$ ) that looks like a loan from (or into?) Sab. No other Sem. parallels.

(4) Cha. gädär // Also in Eža, Gyeto, Masqan (LGur 264, no etymology adduced). May be tentatively compared either with Wol. and Zway gädärä 'to grow up (child)', Amh. (tä)gäddärä 'to germinate' (with the semantic shift 'produce new plants' > 'new'; for broader connections v. BIG No. 8) or, with an $-r$ root extension, to Sem. * gadì $/ \bar{u} d-(\# 2)$.

(5) Hrs. heydìn; Mhr. heydìn; Jib. odin // < MSA *waydìn-. If these forms could be analyzed as *wady-Vn (for the -Vn- suffix in MSA cf., e.g., Jib. Zams̃ina, Soq. Zamšin vs. Hrs. yemši, Mhr. yemše 'yesterday'; or Mhr. diminutive tawēy-ēn < tāywi 'meat'), comparable with Arb. wadiyy- 'premiers germes d'un palmier qui sortent de la terre' (BK 2 1513), with the primary meaning 'new, young'.

$\square \quad$ Should be further connected with Egyp. (MK) id 'young man'; C. Chad.: Matakam wúdá, Zime-Batna údò 'children', perhaps allowing to reconstruct Afras. *wayd- (ADB).

$\diamond$ Gaf. wayä, together with several Gurage languages (LGur 666) is a loan from HEC (Kambatta, Sidamo hāro, Hadiya hāri-ččo), according to LGur 673, "with loss of $r$ through palatalization"; Soq. gedíd must be an Arabism.

$\rightarrow$ Common North and West Semitic *hadit- (\#1).

60. NIGHT

(1) Akk. mūšs; Sod. məšät; Cha. məšätä // < Sem. *(2a-)mVšy- 'night, yesterday, evening' (ADB): Eblaite /mūšum/ 'night', Hbr. 2ämäš 'last night, yesterday', Arb. 2amsi, musy- 'yesterday, masāz- 'evening', Gez. maset 'evening, twilight', Tgr. maset, Tna mašät, Amh. mašet 'evening', Hrs. yemši, Mhr yemšēe, Jib. Zams̃in, Soq. Zamšin 'yesterday' (Hrs.-Mhr. $y$ - instead of *?and, especially, MSA -š/ $\tilde{s}$ - vs. Arb. -s- speak against judging these forms as Arabisms, which they may resemble upon first glance).

$\square$ < Afras. *(2a-)mas(y)- 'night, evening' (ADB): Egyp. (OK) msw-t, (MK) msy-t 'supper, evening meal'; C. Chad.: Gudu məšü 'evening', Logone méése 'midnight', (?) Daba àmusku 'yesterday'; Cush. N.: Beja amas 'late evening, night, twilights' (hardly < Arb.), ámse 'today' (perhaps an Arabism), S. *2amas-: Iraqw, Gorowa amsi, Alagwa, Burunge amasi 'middle of the night', Qwadza amasi-ya 'tomorrow', Asa eramesa 'night' (with a secondary - $r$-); N. Omot. *2umars-:7 Wolaita 2omársa, Malo 2omars- 'night', Gofa 2umarsa, Dorze omarsa 'night, evening', etc. (ADB; cf. EDE III ${ }^{8} 558-562$ and 630).

(2) Ugr. ll; Hbr. laylā; Pho. ll; Bib. lēly-ā; Pal. lēlē; Syr. lely-; Mnd. lily-; Urm. layl-; Qur. laylat-; Leb. layl; Mec. layl; Mlt. leyla; Sab. lly; Gez. lelit; Tna. läyt-i; Tgr. lali; Amh. let, lelit; Gaf. litä; Har. läyl-i, lēl-i // < Sem. *layl-: Akk. lilāt- (liliāt-) 'evening, night', MSA (< Arb.?): Hrs. léylet (JH86), Mhr. láylat 'night' (JM 259: “in certain contexts only”), Soq. lílhe id.

$\square \quad$ For various suggested Afras. etymologies cf. EDE III 43-44, where they are justly considered "uncertain".

(3) Arg. hadara // < Eth. *hdr: Gez. hadara 'reside, dwell, stay overnight', Tna. hadärä 'stay overnight', Tgr. hadra 'dwell, stay', etc. (LGz 258-9) < Sem. *hdr 'spend the night, dwell', *ha/idr- 'dwelling, chamber, tent' : Eblaite /hadrum/, Ugr. hdr (DUL 355; h- is irregular), Hbr. hädär 'room', Pho. h. dr '(burial) chamber', Arb. hddr 'remain and keep to a place', hidr-

${ }^{7}$ As for the secondary r, cf. also Eth. Gur.: Cha., Eža masarä, Ennemor, Gyeto masazarä 'night' and Mil. RE 113.

${ }^{8}$ In EDE III 562, this root is reasonably related with Brb.: Semlal a-mušša, Ntifa muššu and C. Chad.: Padoko musa 'black' (though with a strange formula "remotedly connected" hard to understand to what historical linguistic reality it may refer, and a somewhat unintelligible remark "Note the anomaly with PBrb. *[m]-s-y") and erroneously (ibid. 559-560) with Brb. *ans 'spend the night' and its derivative *ma-nsaw 'evening meal'. 
'women's quarters of a tent' (LGz 259), Sab. hhdr 'chamber, funeral chamber' (SD 59), Hrs., Mhr. hedōr 'to put up a sunshade', Jib hodor id., Soq. hádor 'to build' (JM 438). Surprisingly, the MSA forms are overlooked in all the quoted dictionaries. For the meanings 'stay overnight' and 'night' in Eth. cf. also Arb. hadar- 'obscurité de la nuit' and ḩdr 'ê. très noir' (BK $1544-5)$, perhaps a contamination of two roots.

(4) Arg. etta, yet (syn.); Soq. ḥte // Likely < Sem. * 'ayt- 'time; night' (for this semantic connection cf. \#6 below): Hbr. Sēt 'point in time, occasion, time' (HALOT 899); cf. also what looks like a variant stem *Eant-, with secondary -n- infixed: Ugr. Ent 'now' (DUL 169), Hbr. \&attā 'now' (HALOT 901), etc.

$\square \quad$ If Sem. * Yayt- may be analyzed as * Eay-t-, with the fossilized suffix $-t$, there are possible, if sparse, Afras. parallels: W. Chad.: Montol yi 'time', Angas yii 'year', etc. (unless related with Egyp. (MK) $\imath_{\imath}-t$ 'time, moment'), N. Cush.: Beja $2 \bar{a}$ 'time, period' (more likely < ${ }^{*} \bar{a}$ than ${ }^{*} \bar{a}$, as normally ${ }^{*}\left\{>2\right.$, while ${ }^{*}>>\emptyset$ in Beja); S. Omot.: Ongota $\{u o$ 'night', perhaps allowing to reconstruct Afras. * $\{a y / w-(\mathrm{ADB})$.

(5) Har. artu, ōrtu; Wol. arot // < S.-E. Eth.: Selti arōt 'night', Zway arūt 'evening'; according to LGur 92, from Cushitic (Qabenna aworruta, Sidamo hawarro, Afar harrä are quoted), but the "comparison with Semitic ${ }^{*}\left\{r b,{ }^{*} \dot{g} r b \ldots\right.$ with disappearance of $b \ldots$ is possible." The provenance from Sem. ${ }^{*} \gamma r b$ is more likely than from Cush., since ${ }^{*} \gamma>\emptyset$ in S.-E. Eth., while $* h / h$ (reconstructible for the E. Cush. forms quoted) $>h$ in Har. If this is true, the word is related to Sem. * Jarb- 'sunset, evening, west': Akk. erebu (erbu) 'setting of the sun, west', Arb. farb- 'coucher du soleil', Gez. Sarab 'west, sunset', \{arba 'to set (sun), become evening', Mhr. yarbēt 'strange place, unknown place, abroad', Jib. ofórb 'to go west' (ADB). ${ }^{9}$

(6) Hrs. 2āṣer; Mhr. Eaçar; Jib. Eaçar // < Sem. * Eaṣr- 'feast, time, season, night' (ADB): Hbr. \&ăṣrā 'holiday, celebration, festive assembly', Syr. Sāșart- 'sacrificium', Arb. Sali/ușr- 'temps; saison, moment propre, temps nésessaire; age, siècle, epoque', Zal-2așr- 'le jour et la nuit, ou le soir et le matin', Soq. Sáșer 'temps' (perhaps an Arabism).

$\rightarrow$ Common North and West Semitic (S. Eth.) ${ }^{*}(2 a-) m V s \check{y} y-(\# 1)$.

West Semitic *layl- (\#2).

61. NOSE

(1) Akk. appu; Ugr. 2ap; Hbr. 2ap; Pal. 2p; Qur. 2anf-; Gez. 2anf; Tgr. 2anəf; Gaf. ãf ${ }^{w} \ddot{a} ;$ Sod. afunna; Har. üf; Cha. ãfuna // < Sem. *Zanp- 'nose', including Arm.: Jud. Zappā, Zanpā 'nose; face', Bib. Zanpōhì (with a dual suffix), Syr. Zappē, Zappayyā (pl.), Mnd. anpia 'face' (SED I No. 8).

$\square \quad$ With prefixed ${ }^{*} 2 a-<$ Afras. ${ }^{*}(2 a-)$ nalif- 'breath (> life, soul, heart), blowing of wind' (ADB; cf. EDE I 117-18): Brb.: Ahaggar a-nafo 'breath', Ayr, E. Tawllemmet a-năfo 'fresh humid wind', etc.; Egyp. (OK) nf-t 'fan', (NK) nf 'breath; wind'; C. Chad.: Daba nàp 'to rest, to breathe', Tera nifi 'life', Logone nafu 'life; heart', Fali-Kirya naffa 'heart', etc.; Cush. N.: Beja nifî 'to blow (wind)', E.: Saho naf 'breath, soul, life' (perhaps also Afar neef 'face'), LEC: Somali neef 'breath', naf 'soul; life', Boni nêf 'breath', Baiso neefo 'breath; soul' (perhaps Oromo nafa 'haste, urgency' < “heavy breathing”?), S.: Dahalo afo 'nose' (if < *anf-).

(2) Syr. nah̄īr-; Mnd. nhir-; Urm. nāhīr-; Leb. manhar; Mlt. amniher; Hrs. nherīir; Mhr. nehrīr; Jib. nahrer; Soq. nahrir // < Sem. *nahīr- 'nostril, nose': Akk. nahīru 'nostril', etc. (SED I No. 198).

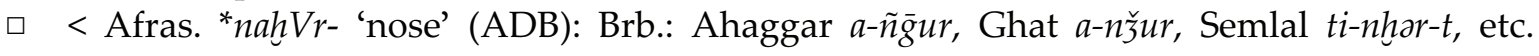
'nose'; S. Cush. *2a-nhari 'phlegm': Iraqw ahari, Burunge anhari. Seems to go back, with the root extension ${ }^{*}-r$, to Afras. ${ }^{*}$ nah- 'referring to the nose, nasal mucus, phlegm ( $>$ saliva),

${ }^{9}$ For an alternative etymology cf. Gez. 2or 'time' (LGz 36) with no Sem. parallels (cf. Egyp. (Pyr.) $r r$ 'time' and C. Chad.: Higi-Nkafa $r i$ 'time'); on the semantic connection between 'night' and 'time' see Nos. 4 and 6. 
etc.' (ADB), perhaps onomatopoeic: Sem.: Akk. nahnahatu 'nose cartilage', Syr. nahnaht'tonsillae', Arb. nuhmat- (with fossilized suffixed $-m$ ) 'ce que l'on jette par la bouche ou par le nez, comme pituite, glaire, etc.', Jib. nhoh 'phlegm' (SED I No. 197); Brb.: Ghadames nohnoh 'speak through the nose'; Egyp. (Pyr.) nh 'saliva; spit out'; E. Cush.: Yaaku núka? 'nose' < ${ }^{*} n u g-$ (if - $g$ renders * $h$, which is not clear; perhaps < ${ }^{*} n u k$ - then to compare with S. Omot.: Dime nuku, Hamer, Ari nuki id.).

(3) Mec. h̆ušum // Class. Arb. hayšūm- 'cartilages du nez' (BK 1 578). Cf. Soq. in-háâsim 'sneeze' (LS 194), unless < ‘hŝm (compared with Mhr., Jib. háŝm 'phlegm' in DRS 934); most likely, a variant root with a plausible semantic shift.

(4) Tna. Zafanç̌a; Amh. Arg. afança // An enigmatic word, with no parallels in other Sem.

$\square \quad$ The only possible parallel is Egyp. fnd 'nose', possibly < ${ }^{*} f n V c ̧ / c ̧ c \mid c ̧$-, but alternatively < *fVnVg-, comparable with Chad. W.: *fVng- (Hausa fàfungà 'toothless mouth', Siri vengi 'mouth', Sura Angas Fyer fur 'hole', C.: Mulwi fingí 'wipe one's nose', etc.) and, with metathesis, N. Cush.: Beja ganuf 'nose' (ADB; cf. EDE II 575-8 containing all the above comparanda plus a weak cognation with Afras. $\left.{ }^{*} f-n\right)$.

(5) Wol. bärbäre // Leslau (LGur 151) speculates about possible connections with bärbäre 'pepper', quoting the same semantic shift in Gogot anfuna 'nose' and 'pepper' (note, however, that in Wolane it may be 'pepper' > 'nose' only, while in Gogot it is vice versa).

$\diamond \quad$ No term in Pho., Bib. and Sab.

$\rightarrow$ Common North and West Semitic *2anp- (\#1).

Common West (Arm.) and South Semitic *nahìr- (\#2).

62. NOT ${ }^{10}$

(1) Akk. ul; Hbr. 2ăl; Pho. 2l; Sab. 2l; Amh. al...(m); Arg. al (...w/u); Gaf. al; Sod. al-; Har. al; Wol. al-; Hrs. Zel, Mhr. Zal (... la?), Jib. Zol (...lo?); Soq. Zal, ol // < Sem. *2al, with a var. *2ul in Akk. and Ugr. 2al, a negative functor (DUL 46).

$\square$ < Afras. *2a/ul: Brb.: Seghrushen, Shenwa, Mzab ul, Mațmața ūl, Zwara, Nefusa wal 'not'; E. Cush.: Afar alēy 'no', Saho zallō 'nothing', LEC: Arbore (má...) ala; N. Omot.: Kafa, Anfillo allo, Bworo āli 'there is not' (ADB; ND No. 24).

(2) Akk. lā; Ugr. l; Hbr. lō(2); Bib. lā; Pal. lāa; Syr. lä; Mnd. la; Urm. lā; Qur. lā; Hrs. lar; Mhr. (2al...) la?; Jib. (2ol...) lo2 //< Sem. *la? (perhaps eventually related, with metathesis, to * $2 a / u l)$.

$\square \quad$ Cf. scarce parallels in other Afras.: C. Chad.: Makeri la 'not'; C. Cush.: Bilin, Aungi la- id.

(3) Pho. 2y; Gez. 2i; Tna. 2ay (...n); Tgr. $2 i / /<$ Sem. *2ay: Akk. ay, ē, prohibitive, Hbr. $2 \bar{\imath}$ 'not' (HALOT 38, hapax), Arb. ?a-, Soq. ?ē 'not' (ND No. 3).

$\square \quad$ With a few Afras. parallels, probably allows for Afras. *2ay: Egyp. (OK) iw.i 'welcher nicht' (quoted in ND No. 3 with two question marks); E. Cush.: HEC: Burji -ayz, Hadiya -yyo, suffixed negative markers of verbs (ibid.); S. Omot.: Ari -ai 'no', Dime Reekai (< 2ee-kai, cf. Basketo -kkaye, Chara káyay, Seze keìzìw 'not') id., Ongota (ma-)...-2i 'not' (ADB; ND No. 3).

(4) Qur. $m \bar{a}$; Leb. $m \bar{a}$ (...š); Mec. $m \bar{a}$; Mlt. $m \bar{a}$; Amh. (al...) $m$, Gaf. $-m$ // < Sem. ${ }^{*} m a(2)$ : Har. $m \bar{e} ?$ 'no!' (LHar 102).

口 < Afras.: Egyp. (OK) $m$ 'do not!'; Brb.: Ayr ma, Shawiya ma 'not', Nefusa mō 'no', Tazelwalt a-mia 'nothing'; Chad. W.: Chip ma, Goemai mou, Tangale $-m$, Bade - $m$ 'not', C.: Bura am (met.) 'no! never!', Glavda maay, Gisiga, Masa máy, Lame mì, Zime-Batna, Zime-Dari mì 'not'; Cush. C.: Khamir -m 'not', E.: Afar ma-...(-in), Saho mā-...(-in), LEC: Somali már (...in), Boni mo/a/i, Rendille, Dasenech, Arbore ma-, Elmolo má-, Oromo (Wellega) mū 'not' (cf. also Yaaku -meá- 'dispense with'), S.: Iraqw ma 'do not!'; Omot. N.: Yemsa miyo

${ }^{10}$ The forms below are not marked (syn.), since their functions are differently distributed in most cases. 
'ban, prohibition', S.: Hamer m- 'not, no', -ma 'no', Ongota ma- (...-2i) 'not' (ADB; EDE III 13-14).

(5) Tna. (2ay...) n; Cha. an- // < Sem. *2ayn- '(there) is not': Akk. ya?nu, yānu 'is not', Ugr. Zin, Hbr. Zēn 'there is no', ?ayin 'non-existence; nothing' (HALOT 41-42), Cha. enä, Gyeto enätä, Eža, Masqan, Gogot ennä 'there is not' (LGur 54).

$\square$ < Afras.: *2ayn- (<*aay-n?) *nay- (<*n-2ay?): Egyp. (Pyr.) n 'not' (Coptic n-), (NE) (bn ...) in 'not' (Coptic an); Chad. W.: Zakshi, Zangwai nai, Tala nú, Juu nu 'not', C.: Bana yyáà, Malgwa ya 'no'; E. Cush.: Afar (ma-...) -in, Saho (mā-...) -in 'not', LEC: Somali (má-...) -in, Dase-

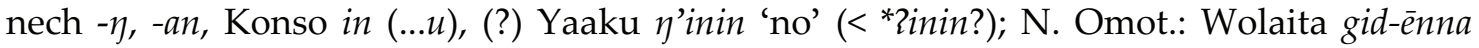
(gid- 'be'), Kullo, Gofa gid-enna, Chara an-,Yemsa aìnè 'not' (ADB; cf. ND No. 48).

$\rightarrow$ Common Semitic * $2 a /$ ul.

Common Semitic *lar.

63. ONE

(1) Akk. Zištēn m., ištiat f. // < Sem. * 'Sišt(-Vn/t)- 'one; eleven': Ugr. (DUL 190) Ššt(y) 'one' (less

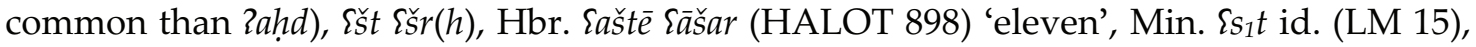
Qat. $\left\{S_{1} t-n-m\right.$ 'one' (Ricks 125).

$\square \quad$ Sem. *Sišt $(-V n / t)-<$ *Siš-t- (with a fossilized *-t suffix) continues Afras. * Eis-n/t- 'one' (with $-n$ masculine and $-t$ feminine suffixes?): Chad. *say/w(-t)- (met.): W.: Hausa sàu 'times' (sau $u k u$ 'three times'), Angas šii, Goemai shà id. (or < Hausa), Guruntum ša 'one' (St. 2009 \#38a), C.: Mafa sátá-ḍ 'one’ (id. 111), Podoko saya 'seul'; Ouldeme sáy 'sauf, seulement', E.: Mokilko sò 'one; suffix of singularity'; N. Omot. *is-ta/na 'one': Wolaita issō, istā, issinō, Gamo, Dorze, Cancha issino, Dawro itta (assim. < *ista), Zala ista, Dache isiyno, Chara issá, Yemsa isa, isson, Dizi (Nayi) isn, etc. (ADB).

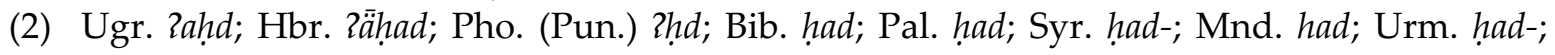
Qur. wāḥid-; Leb. wahad; Mec. wāhid; Mlt. wịhet; Sab. 2hd; Gez. Zaḥadu; Tna. hadä; Tgr. hatte f. (woro m.); Amh. and; Arg. hand; Gaf. ažz̆ä; Sod. at(t); Har. ahad; Wol. add; Cha. at // < Sem. *(2/wa-)had- 'one, single, alone, united': Akk. wēdu 'single, sole, alone' (CDA 438), Hbr. yhd 'to be united' (HALOT 405), Arb. whd 'to be alone' (ibid.), Gez. wāhad 'unique, only, one' (LGz 609; Gez. wehda 'to be few', quoted in HALOT 405 as wehda, is a different root), Mhr. waháyd 'alone, solitary, liking to be on one's own' (JM 425; Hrs. wāhid 'one (in telling time)' in JH 135, is an Arabism), Jib. ahdi 'by oneself, all alone', š-êhad 'to unite' (JJ 289), etc. (cf. DRS 831-2; in Kog. LE n. 68, the MSA forms "are likely borrowed from Arab.", which is debatable, especially in view of Soq.), Soq. hōd 'couple (homme et femme)' (LS 166 with no etymology, but both phonetically and semantically - as 'union' - fairly fitting).

口 < Afras. *(2/wa-)had- 'one': Chad. daHw/y- *waHid- 'one’: W.: Hausa dáyá (< *daH-), Karekare wádì, 2zwádí (< $\left.{ }^{*} H^{w} a d-\right)$, C.: Munjuk daw, Nzangi hidō, Bachama hído, Bata hido, Musgu deu, day, Zime-Batna daó, ḍāur, Masa deu (cf. also Logone səy-día), E.: *ka-yiḍ- (ka- 'head'):

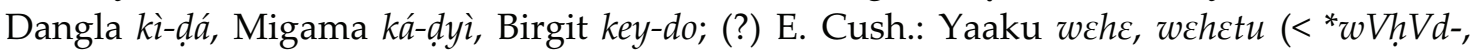
with hypercorrection in wehk, where $-t$ was perceived as a feminine suffix and dropped?).

(3) Hrs. țād (m.), țat (f.); Mhr. țāṭ (m.; LS 199 quotes țad), țáyt (f.; same in LS); Jib. țād (m.), țit (f.) (JM 406); Soq. țad (m.), țey (f.) (LS 199) // An enigmatic term. Beside an isolated Qat. țd 'one' (Ricks 77), this looks like a loan from some early stage of MSA, the only hypothetical parallel I could find is Arb. țuzan (<*twz) 'quelqu'un' (BK 2 116). ${ }^{11}$

$\rightarrow$ Common West Semitic *(2/wa-)had- (\#2).

${ }^{11}$ If this comparison is acceptable, the MSA term should be analyzed as *tay-/*tay-t, with an unexpected voicing ${ }^{*}-t>-d$, perhaps a dissimilation due to the complete incompatibility of $t$ and $t$ as root consonants in 


\section{PERSON}

(1) Akk. Zawìlu // No plausible Sem. parallels.

$\square \quad$ The only tenable Afras. etymology (for a similar semantic shift v., e.g., MAN Nos. 3, 7, 10) is (Ha)wil- 'child' (ADB): Brb.: Nefusa illi, Ahaggar ul-st, E. Numidian wl-t 'daughter' (cf. Zenaga $i \check{3}$ 'man' < ${ }^{*} H i l$, unless < ${ }^{*} H i l l-$ 'to be, exist'); Chad. W.: Bokkos Rál, Sha hál 'child', E.: Mokilko \{ùló, Somrai wīl 'child'; Cush. E.: Afar il(i)mo 'bastard' (with suffixed -m), LEC: Somali wi(i)l 'boy', wáláal 'brother; sister', Boni wecl 'child', Rendille walal 'brother', HEC: Sidamo, Kambatta il- 'to give birth', S.: Asa ille-to 'daughter'; N. Omot.: Dorze yelo(?) 'boy', Koyra yelē 'child', yel- 'be born', Male às-éll-ó 'person female'.

(2) Ugr. bnš (bu-nu-šu < bn nš); Hbr. 2änōš; Bib. (bar-)2ănāš; Pal. brnš, 2ă̈naš; Syr. bar-(2)nāš-; Mnd. (a)naš-, barnāša; Urm. barnāšs-; Qur. Zinsān-; Leb. Zinsēn; Sab. ¿nss ${ }_{1}^{*} / /<$ Sem. *(bin/bar-) 2i/a-naš- (v. Afras. cognates in MAN No.5).

(3) Pho. $2 d m^{12} / /$ also 'man, someone' < Sem. *2adam-: Akk. adamu 'an important, noble person' (CAD a1 95: LL), 'eine Person' (AHw. 10), Ugr. 2adm 'man, mankind' (DUL 17); Hbr. ₹ādām 'mankind, people; individual man; Adam' (HALOT 14), Sab. 2dm, 2dwm-t, 2dym 'vassals, servants, adepts' (SD 2), Qat. $2 d m$ 'men, people; subjects, vassals (of a king, etc.)' (Ricks 5), Arb. (Daț., Hụ̂r.) Zawādim 'people, mankind',13 Jib. bírdém (JJ 27) ${ }^{14}$ (v. Mil. SE 238-9; ADB).

$\square \quad$ Perhaps < Afras. *(2a-)dam- kin, family member(s)' (ADB): ${ }^{15}$ Chad. W.: Mupun adâm (pl. dande) 'legitimate child', C.: Podoko dama 'brother, sister', Cuvok dèm 'daughter', dàmà

MSA.While $t$ and $d$ are also incompatible in continental MSA (with the exception of *tad-), there are at least two more cases of $t$ and $d$ in one and the same root in Soq., perhaps reflecting the proto-MSA (in)compatibility pattern: țádah 'dos' and țádi 'provision' (LS 199). In view of this, somewhat far-fetched reasoning, one may surmise that the Proto-MSA masculine form was *tā- $t$, with the singulative suffix $-t$, later perceived as the second radical, incompatible with the first one, and thus voiced, whereas the feminine form ${ }^{*} t a y$ acquired the feminine suffix $-t$ in "Proto-Continental" MSA (after the separation of Soq.), which was then duly perceived as a suffix and, hence, was not subject to the root consonants' incompatibility pattern.

${ }^{12}$ I realize, of course, that it is highly conventional to ascribe such differences in meaning as 'person' vs. 'man' to the terms under discussion in languages where they are scarcely attested, like Pho, Ugr. or Sab.

${ }^{13}$ Both are pluralia tantum from the unattested singular form *2ādam- and may as well continue the common Semitic term, since they do not look like loanwords either from classical Arb., where the plural 'men, people' is expressed by the word combination banū zādam- 'sons of Adam', or from the quoted ESA forms with somewhat different semantics, or from Hbr. ¿ādām. While Class. Arb. ¿ādam- 'Adam, forefather of mankind' (BK 120 ) is more likely borrowed from or influenced by the Hbr. word, it is not necessarily so for 2ādamiyy- 'human' (ibid.). The same can be said about Gez. Zaddām 'Adam' and Zaddāmāwi 'human' (LGz 7). There are also Tna. Zaddam 'humanity, mankind, everybody' and Tgr. 2addam 'people, men' (pl. 2addamatat 'crowds of men', ?addemay 'little man' LH 384), whose meaning and collective plural make the possibility of borrowing from Arb. or Gez. very doubtful.

${ }^{14}$ The first stem of this compound form, bir , casts certain doubts on the possibility of direct borrowing from Arb. (cf. the Omanic Arb. bin 2ādam-) with the reinterpretation and replacement of the first component by its Jib. equivalent. The alternative, though less likely, is that the term is inherited from Proto-Semitic. Note that rendering of the notion 'man, person, human being' by the compound word with the first component 'son' goes back to a much earlier period (see \#2) than the beginning of Arabic influence on MSA.

${ }^{15}$ Not quite solid because of its scarce representation in Afras., yet this etymology still seems more tenable to me than various alternative etymologies of Sem. *2adam- (for them and their parallels in other Afras. see Mil. SE 249-252). Interestingly, there is another, better represented Afras. root, presumably related to or contaminated with this one, namely ${ }^{*}(2) d m$ 'to participate, join, be part of an aggregate/clan, comprise a whole' (ibid.; ADB): Sem.: Akk. (Ass.) adāmu 'to own a share in a common fund' (CAD $a 1$ 95), admūtu 'share in a common enterprise' (ibid. 128), Arb. $2 d m$ 'to join, aggregate; reconcile; integrate someone into one's clan', Gez. 2adamdama (redupl.) 'to go together (army)' (LGz 133); Egyp. (OK) dmy 'to join, be attached to so.', (MK) s-dmy (caus.) 'to attach (of family attachmnent)', (NK) dmy 'to share with so. (joy, crops)'; Chad. W.: Tangale dom 'to collect, put together', Boghom dume 'to gather' (cf. perhaps also Hausa doma 'to urge smb. to an evil course'), C.: Zeghwana dámme 'together', ba 
'sister', Sukun dam 'daughter; female', E.: Bidiya nii-dimo, pl. mii-dime 'boy'; (?) S. Cush.: Asa da?am-ok (with metathesis, if belonging here) 'elder, married man'.

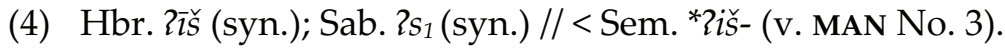

(5) Pal. gebar; Urm. (both syn.) gabr-// v. MAN No. 4.

(6) Mec. šahș // Class. Arb. šahș- 'personne, individu' (BK 1 1202). A rare root composition of radicals leaves only one possible etymology, namely, < Sem. ${ }^{*} \hat{s}_{x} h s^{16}$ 'to be high, great, lofty (> haughty)': Arb. šhș (a) 'ê. él e vé s'élever', šhș (u) 'ê. grand, gros', šahīṣ- 'grand, gros, considerable, marquant (homme, personnage); seigneur, maître' (BK 1 1202), ${ }^{17} \mathrm{Hbr}$. (hapax in Job 28:8) šăḥaṣ 'size, pride' (HALOT 1463), pB. šaḥaș 'pride, conceit', šḥs (pi.) 'to strut', (hitp.) 'to hold oneself aloof', Jud. šaḥs- 'pride' (ibid.), Gez. ŝạ̦̣a (with irregular ḥ, which must be a scribe's error) 'be insolent, arrogant, insult, offend, etc.' (LGz 528).

(7) Gez. bazas-i // also 'man, male, husband, someone' (v. MAN No. 7).

(8) Tna. säb; Amh. säw; Arg. su; Gaf. säwwä; Sod. säb; Har. usu?; Wol. säb; Cha. säb // v. MAN No. 9.

(9) Mhr. nafs; Jib. nafs // 'person, individual' (probably influenced by rather than borrowed from Arb. ${ }^{18}$ ) < Sem. ${ }^{*}$ nap $(i)$ š- 'soul; vitality, life; person, personality; self' (related to *npš 'to breathe', cf. SED I Verbal Roots \# 46, 47)

$\square$ With Afras. parallels, some of which, however, may be loans from Sem. (ADB): Brb.: Izayan unfus, Ahaggar unfas 'respiration', Ayr anfas, E. Tawllemmet infas 'respiration; vie', Semlal sūnefs 'respirer', etc.;19 Chad. W.: Hausa númfàasaa, lúmfàasaa 'breathe; take a rest', Bokkos lafos, Sha lufwos, Daffo-Butura nafos 'breathe' (St. 2005 \#390a), C. (met.): Mofu -safn-, Musgu súmfa, Munjuk sinfi 'to breathe' (St. 2009 \#65)20; Cush. C.: Aungi nefes-an 'blow', E.: Saho nafse 'breathing' (both likely < Eth.), LEC: Boni neefso 'breathe', Rendille nefs'í 'breath', nefsó, nefs'-áda 'breathe' (hardly < Amh.) $)^{21}$

(10) Soq. hay (Kogan MS: héyhi) // the original meaning likely being '(the) living (one)' < Sem. *hwy 'to live' (v. in HALOT 309, LGz 252).

$\square$ < Afras. *hayVw- 'live, be born, give birth to' (ADB): Brb. *Hiway 'be born': Ayr ahw, E. Tawllemmet ahw (ăsaho 'native of'), Ahaggar iwi; Chad. ${ }^{*} H a y$ - (if < ${ }^{*}$ hay-, unless < ${ }^{*}$ hay-): C.: Tera hya, Margi iyà, Higi ỉya, Matakam ya, etc. 'give birth', E.: Somrai yá, Kabalai yàyà

dámme, Nakatsa bà dámà 'all'; Cush. C.: Khamir edem, yedem (<*2adam-?) 'to invite to a fiest', E.: Afar adm-is, LEC: Oromo (h)adama, Arbore 2adam-is, Dasenech adam- 'to hunt' (as a collective action?), HEC: Hadiya dumm- 'to gather (of people)', dumm-ičča 'gathering of elders', S.: Iraqw dam- 'to copulate'.

$16{ }^{*} \hat{S}_{\mathrm{x}}$ (instead of $\left.{ }^{*} \hat{s}\right)$ is tentatively reconstructed on the basis of the correspondence Arb. $\check{S} \sim \mathrm{Hbr} . \check{s} \sim \mathrm{MSA} * \check{S}$ (on

${ }^{*} \hat{s}_{x}$ see, e.g., SED I XCVIII-CV). While Sem. ${ }^{*} \hat{s}$ continues Afras. ${ }^{*} \hat{c}$, Sem. ${ }^{*} \hat{s}_{x}$ reflects Afras. ${ }^{*} \hat{s}$.

${ }^{17}$ According to Lane's explanation, "it is applied... to a body, or material substance, composed, [not simple,] and having height... or any body, or material thing or substance, [that is somewhat high, and conspicuous, or] having height and appearance... Then used as signifying A man himself; a man's self, or person." (Lane 1517).

${ }^{18}$ This assumption is sustained by two arguments: (1) in both languages, the root $n f f_{s}$ with related verbal meanings (e.g. Mhr. antafūs, Jib. antfés 'to be safely delivered (of a child)', Mhr. ša-nfūs, Jlb. s̃a-nfés 'to welcome so.', Jib. antfés 'to sigh', etc.) is well represented, (2) the root is widely represented in all Sem. and MSA languages (on this argument for interpreting a term as inherited rather than borrowed see SED I LIV). It is an unsettled problem in lexicostatisics: should one eliminate such cases from the scores or give them the same score as the "influencing term" in another language?

${ }^{19}$ The form of the Brb. words and their wide attestation are arguments against borrowing from Arb., although it cannot be ruled out completely.

${ }^{20}$ Considering these forms to be derivatives with $-n-/-m$ - suffixation from *sVf- 'to breathe', which is debatable.

${ }^{21}$ Heine (SAM 1978 70) compares the Boni and Rendille forms with Somali neef and Boni nêf, which is improbable. 
'give birth', Mokilko Zériyó 'birth'; Cush. N.: (?) Beja haay- 'live' (acc. to LGz, < Eth.), E.: Saho, Afar hay id. (acc. to LGz, < Eth.), HEC: Hadiya hee?-, Kambatta he2-, Burji ye-d 'live'.22

$\diamond \quad$ Mlt. persūna, most probably < Italian; Tgr. näfär < Arb.; Hrs. benēdem, Mhr. menēdem (syn.) $<$ Omanic Arb. bin Zādam (JH 18).

$\rightarrow$ Common West Semitic * (bin-/bar-) )i-naš- (\#2)

\section{RAIN}

(1) Akk. zunnu; Sab. dnmm; Gez. zanām; Tna. zanam, zanab; Tgr. zalam; Amh. zanab; Arg. zanab; Gaf. zanab ${ }^{w} \ddot{a}$; Sod. zanab; Har. zanāb; Wol. zalam; Cha. zarab // < Sem. ${ }^{*}$ unn(a)m- (DRS 336) with phonetic variations due to low compatibility of $-n-$ and $-m-$.

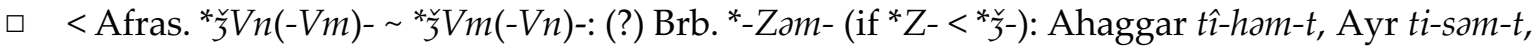
E. Tawllemmet ti-šam- $t$ 'réservoir artificiel'; C. Chad.: Bana nzámá 'pleuvoir', Gude nzama

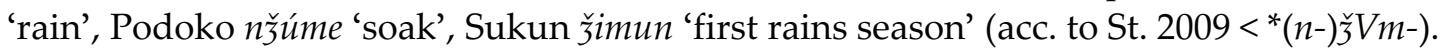

(2) Ugr. mțr; Hbr. māțār; Pal. mṭr; Syr. mețr-; Mnd. mițr-; Urm. mițr-; Qur. mațar-; Mec. mațar // < Sem. *mitar-: Akk. mițirtu, mițru 'watercourse, canal; a type of irrigation' (CDA 213).

$\square$ Comparable, with a fossilized prefix $m$-, to several scarce terms possibly allowing to reconstruct Afras. *(mi-)tar(ar)- (ADB): Brb.: Ahaggar e-drer 'sprinkle'; etc.; Chad. W.: Hausa tàrarà 'drip or pour out', Jimi taari 'flow', E.: Migama tárró 'water flow'; E. Cush.: LEC: Somali darer 'dripping' (note a coincidence of two radical $-r$ in most of the forms). ${ }^{23}$

(3) Hbr. gäs̆äm (syn.) // < Sem. * gašm *̌s̆gm 'rain; pour': Ugr. gšm 'rain, downpour' (DUL 310; Kog. Ug-Can 24 and n. 68), Syr. *šegm- (in šegmē do-mețrā 'magni imbres' Brock. 755), Arb. š̌m 'couler (se dit des larmes)', IV 'verser (les larmes, la pluie)' (BK 1 1055), Tna. gässämä 'to drink a lot, to quench one's thirst' (Kog. Ug.-Can. 25).

(4) Leb. šitā; Mlt. šita // Class. Arb. šitāaz-, šatwat-, šātāt- 'hiver', ?aš-šatāwityy- 'pluie d'hiver' (BK 1 1190) < Sem. *ŝitaw/2- 'rainy, windy season': Akk. šūtu 'south; south wind' (CAD šs 4089), Hbr. satāw (s- instead of the expected * $\hat{s}$ - suggests a loan from Arm.) 'rainy season, winter' (hapax in Song 2:11), Old Arm. štw, Syr. satw-, Jud., Mnd. sitw- ib. (all in HALOT 77071), Mhr ŝêtaw, Jib. ŝ́te? 'winter', Soq. séta 'north, north wind' (JM 387; Arabisms are likely in Mhr. and Jib., but less so in Soq. because of the meaning difference), etc.

(5) Tna. may (syn.) //< Sem. *mar/y- 'water' (v. WATER No. 1).

(6) Hrs. me-lsēn; Mhr. ma-lsi; Jib. mó-sć; Soq. me-se $e^{24} / /<$ Sem. *liš(lVš)- 'efflux, outflow': pB Hbr. lišläšät 'secretion, chicken's dirt, spittle' (Ja. 720), Jud. lišlūšat- 'foam (of nostrils)' (ibid.), Syr. lšlwš 'mucus' (Brock. 371).

(7) Hrs. rehemet; Mhr. rehemét; Jib. rahmét (all syn.) // Considered a metaphor < Sem. *rḥm 'to be merciful, kind' < Sem. *rah.(i)m-/*rihm- 'womb' (SED I No. 231).

$\diamond \quad$ No term in Pho. and Bib.

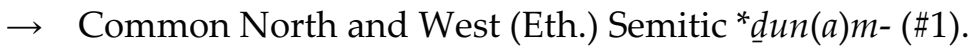

Common West Semitic *mițar- (\#2).

66. RED

(1) Akk. sāmu // 'red' (CAD s 126), 'rot, braun' (AHw 1019); represents a rare case of a sibilant rendered by the SA SI SU series, regarded by Goetze as a separate Sem. phoneme ${ }^{*} S_{x}$ re-

${ }^{22}$ According to EDE III 656, Egyp. (Pyr.) hww 'food' may be cognate with Sem. *hyw *hwy 'to live'; that source quotes are direct Afras. parallels to the Egyp. root: E. Chad.: Somrai hàyē, Ndam āy 'food'; S. Cush.: Asa haiu-g id.

${ }^{23}$ For alternative, less tenable interpretations see EDE III 737-8.

${ }^{24}$ Also lí(y)soh 'pleuvoir' (compared in LS 234 with Arb. lty 'ê. mouillé, humecté' with an irregular correspondence between the second radicals: Arb. $\underline{t}$ corresponds to Soq. $t$ ). 
flected in Hbr. as both $\check{s}$ and $\hat{s}$ (v. discussion in Bulakh. Akk. 7-8). In spite of the irregular reflexation of ${ }^{*} \check{s}$ as $s$ in Akk (it should be $\check{s}$, though several more cases of this irregularity have been encountered), it was compared by Bulakh (ibid.) to Ugr. šmt denoting red color and, alternatively, after Goetze, to Hbr. šōham denoting some precious stone (note that Akk. sāmtu is 'a red stone, mostly designating carnelian' CAD s 121, likely derived from sāmu, cf. AHw 1019). Another parallel for Akk. sāmu, now with regular correspondences, is Arb. sahm- 'noir' (BK 1 1063), with both going back to Sem. *sahm- 'red, black'.

$\square \quad$ Both options, for a Sem. root with *s- (with a problematic second radical) and for *sahmhave possible parallels in C. Chad. * ${ }^{*} V m-s V m$ - (St. 2009 \#287) 'yellow' (otherwise $<{ }^{*} \mathrm{cVm}$ $c V m$ - as, according to Stolbova ibid. 7, none of these languages distinguish between the reflexes of Chadic ${ }^{*} s_{-}$and ${ }^{*}{ }^{*}$-):25 Boka šummaà, Hildi mī-šišimāa, Gude šišima, Zelgwa sisím sisím, and C. Cush. *šaman- 'black' (according to CDA 34, derivatives of *cam-): Qwara, Kemant šämäna, Falasha čamana or šamana. Note also S. Cush. *ce?am-: Iraqw cezama 'sun', Qwadza cerema 'bile' (acc. to HRSC 355, < 'yellow'; compared with Akk. siāmu, sâmu 'rot, braun s.' in Tak 2001 3), which is compatible with the Akk. root, but neither with Sem. *̌snor with * sahm-.

(2) Ugr. 2dm;26 Hbr. 2ādōm; Cha. dämyät // < Sem. ${ }^{*}(2 a-) d a m-$ 'dark red': Akk. dåmu (met.?) 'dark-colored, dark-red' (CAD d $74<$ dąāmu 'become dark' ibid. 1)27, (?) Sab. 2dmhy (v. discussion in Bulakh Hbr. 200-201), Arb. \{udmat- 'red color' (Blachère 63), dmm 'teindre en rouge' (BK 1728 ), Gez. Zaddāmāwi 'red' (LGz 8), Tna. dama 'blackish (horse's coat)' (Kane T 2061), Amh. dama 'dark red (horse's coat)' (Kane A 1720), Har. dāma 'brown, of dark color (man)' (LHar 56), Zway diimä 'red'. ${ }^{28}$

$\square$ < Afras. ${ }^{*}(2 a-) d V m-\sim{ }^{*} d i 2 m-~ '\left(\right.$ dark) red' (ADB): Brb. ${ }^{*}-d V m(d V m)-:$ Tamazight adamman 'brown, bronze coloured', Shilh adammani 'brown, bronze coloured' (N-Z 343), Qabyle ddamdam 'violet'; Egyp.(OK) 2dmy 'red linen cloth'; Cush. C.: Aungi dámmá, Kunfäl demé 'red', E.: Saho duma 'red', LEC: Oromo díma?, Konso tīm- 'red', HEC: Darasa duu?mo 'red', Darasa diimma 'become red', S.: Qwadza dimayi- 'red'; Omot. N.: Kafa damme 'red', S.: Ongota damazta 'yellow'. Probably related to Afras. *dam- (with a variant stem *2a-dam- in some Sem.) 'blood' (ADB), as early as on the pre-Proto-Afras. level.

(3) Pal. swmk, symwk, smwk; Syr. sūmāk-, summāk- (also 'sumac' Brock. 482); Mnd. sumak-; Urm. samūk- // < Sem. *sumāk-? Cf. Arb. sumāk- 'ce qui est pur, franc, sans mélange' (BK 1 1141) and Akk. sameka, a plant (CAD s 114). Otherwise, could be compared with Arb. 2ašmak- 'écume mêlée de sang que jette un chameau' (BK 1 1271), then < Sem. *ŝumāk'red(dish)' (see Bulakh Dis.)

25 This root is equated (ibid.) with ${ }^{*} \mathrm{sVm}$-sVm- 'kind of tree with yellow fruit or bark', containing Mafa šéšémthat points to ${ }^{*} s-$, but it can alternatively go back to Afras. * simah- kind of tree, bush' (ADB), perhaps having taken the 'yellow' element in some of the forms due to contamination.

${ }^{26}$ The verb 'become red'; for the meaning cf. Kog. Ugr.-Can. 10: "the supporting evidence is more etymological than contextual". Both these factors probably demand the elimination of this Ugr. form from the final scoring.

${ }^{27}$ For an alternative etymology $<* d h m$ see Bulakh Akk. 198.

${ }^{28}$ According to Bulakh Hbr. 201-2, where my equation of the Gur. forms with this root is doubted because "the first laryngeal (or any traces of it) [are] missing" (cf., however, the Tna and Amh. terms, Akk. darmu and Arb. $\mathrm{dmm}$ ) and "in view of the fact that a plausible Cushitic etymology can be suggested for these terms" (which is a weak argument per se), all Mod. Eth. forms are borrowed from E. Cush.: Darasa diimmo 'lean meat, red', Sidamo daama 'red', Afar dum 'finster, dunkel werden', Oromo diimaa 'red, red-brown; raw' (Burji duwwaa 'red', stereotypically equated with this root, is not related because *-m-does not normally yield Burji - $w$ - and because it has a different, and quite plausible, Afras. etymology). Though the borrowing into Mod. Eth. from E. Cush. (and vice versa) is not impossible, I am still inclined to count this as common inheritance in view of wide distribution both in Sem. and Cush. 
(4) Qur. h̆umr- (pl.); Leb. Mec. Mlt. ahmar, (?) Sab. ḩmrt 'red' (SD 68; syn.) // < Sem. *hamr'red': Akk. ummuru 'a kind of bronze' (CDA 422: LL), 'eine besonders geläuterte Bronze' (AHw. 1417), (?) Ugr. hmr 'red, reddish' (DUL 364; v. Kog. Ug.-Sem. 12), Hbr. hmr (po\{alSal) 'to glow' (HALOT 330; hapax in Job 16:16), Jud. hammār 'dark' (Ja. 480), Mnd. hmr 'to be red, inflamed' (DM 150), Gez. hamr 'kind of color, complexion', hamar 'red berry' (LGz. 234), Tna. hamra 'reddish (bovine coat)', hamray 'reddish, bay, auburn' (Kane T 172), Tgr. hamär 'red-brown (horse, cow)' (LH 384), Amh. hamär 'reddish bay (horse)' (Kane A 7), amär 'bay (horse)' (ibid. 1122). ${ }^{29}$

(5) Gez. kayyih; Tna. käyyih; Tgr. käyah; Amh. käyy; Arg. käyyah, käy; Gaf. käyä; Har. kēh // <

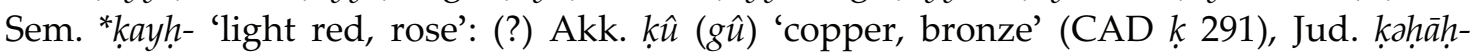
'faint-colored, gray (?)' (Ja. 1345), Arb. kuhḥ- 'pur, franc, sans mélange (en parlant des boissons); non mûr (en parlant d'une qualité, d'une vertu, d'un vice, etc.)' (BK 2 677), kayh. 'pus (qui n’est pas mêlé de sang)' (ibid. 844), (?) Hụr. kyḥ 'red (applied to bronze)' (v. Bulakh Gez. 740-41).

$\square \quad$ For possible Afras. parallels see either (1) Egyp. (BD) khy 'moon' and Chad. * $k V y / w V H-$ 'moon' (in St. 2011 \#181, adducing Egyp. khy as a possible cognate): W.: Duwai kíyà, C. *kiy-: Mofu kiyá, Gisiga, Matakam kíyà, Buduma kyèá, etc., E.: W. Dangla kóyè, Migama kóoyò, Bidiyo koya (all reflecting Egyp.-Chad. *kVyh-, and, if related with Sem., allowing to reconstruct Afras. *kayh- 'moonlight'), or, more problematic, (2) Omot. *2ak- (<*Ha/ik-?): N.: Kafa, Mocha aa?o, Anfillo 2aako, Bworo aaka 'black', S.: Hamar 2kk 'green' (ADB). ${ }^{30}$

(6) Tgr. țala (syn.) // (in LH 606) < Sem. *țll 'to be spotty, have red and white spots' (cf. Bulakh Dis.): Tna. țala 'ashen white (ox’s coat); light brown (cow’s coat)' (Kane T 2398), çelay 'fawn-colored, tawny, beige (lion's, ox's coat)' (ibid. 2495), Amh. țala 'red marks on cotton bolls caused by insects', țalät 'white fleck in the eye, cataract; skin disease which makes dark red scabs and spots' (Kane A 2087), Hbr. țālū? (part. pass., qal) 'spotted (sheep), multicoloured (pillows), patched (shoes)' (HALOT 375), Arb. tullä? 'sang' (BK 2 104), Mhr. țalū 'to paint, colour, daub; to colour (the face), make up' (JM 410), Jib. țélé 'id.' (JJ 278), Soq. țal 'queue blanche d'un mouton' (LS 203).

(7) Hrs. 2áfer; Mhr. 2ōfar (Sófar); Jib. Sófar ; Soq. Sáfer // Very likely < Sem. *Eapar- 'dust, soil': Akk. ep(e)ru 'dust; earth, loose earth; territory, soil; etc.' (CAD e 184), Ugr. Spr 'dust; earth, ground' (DUL 174), Hbr. Sapār 'dust' (HALOT 861-2), Arb. Safar-, Safr- 'terre, poussière'; Sufrat- 'couleur grisâtre de poussière', Zaffar- 'rougeâtre melé; sable rougeâtre' (BK 2 298), Tgr. Säfär 'dust, desert' (LH 492), etc.

$\diamond$ Sod. bəšša; Wol. bušä; Cha. bəša < E. Cush.: Hadiya bišo 'brown', Sidamo biša 'red', Afar bisu, Oromo bifa 'color' (LGur. 161, v. in Bulakh Dis.). No term in Pho. and Bib.

$\rightarrow$ Common West Semitic: *2adam- (\#2).

\section{ROAD}

(1) Akk. harrānu // < harr-ānu (OAkk. on; acc. to CAD ḩ 106, possibly connected with Hurrian hari). Judging by lack of visible parallels with h- (except for Ugr. hrrn 'gang, caravan' DUL

${ }^{29}$ Bulakh (Bulakh Dis.) critically analyzes all Sem. examples given above, placing under doubt the correctness of some of the interpretations, connecting them with red color (in Akk., Ugr., Hbr., Arm. and Gez.), and treating others (Mod. Eth.) as Arabisms; she admits, however, that some of the forms originate from Sem. * $h m r$ 'to be swollen, inflamed (of inner and outer organs)' with a semantic development toward 'to be reddened' (ibid.).

${ }^{30}$ In the latter comparison, as in some others, the problem of consonantal correspondences worries me more than that of semantic differences: variance in color names, even such remote ones as 'red' and 'black', in presumably or evidently the same roots, is surprisingly common in various branches of Afras., and, naturally, even more so in Proto-Afras. roots. 
405 which looks, with its suffix - $n$, very much like a loan from Akk. harrānu, where the meanings 'caravan', 'raid' and 'army' clearly derive from 'road'; for this reason, the comparison of Ugr. hrrn with Gez. harā 'army, troops' < Sem. hlVr- (with various triconsonantizers) 'free' (LGz 240-41), considered in Kog Ugr.-Sem. 20 "semantically more suitable", is untenable. Presumably another case of Akk. $h<* h$ (v. \#5), then < Sem. *harr- * *haw (a)r-: Arb. hâarat- 'quarter of a city' (orig. 'road'?), hwr 'to return', Gez. hurat 'course, walking', hora 'to go, proceed, depart', Har. hāra 'to go', etc. (v. LGz 249, DRS 851).

$\square$ < Afras. *ha(w)r-: Egyp. (Pyr.) hry 'go far from, move away', hr-t 'road'; E. Chad. *Har- 'go': Nanchere áre, Gabri ōre, Kabalai àrrà, Dormo erauá; E. Cush.: HEC: Sidamo hár 'to go' (ADB).

(2) Akk. girru (syn.) // From OB on (CAD g 90) < Sem. * gi/arr- 'path' (possibly the one leading

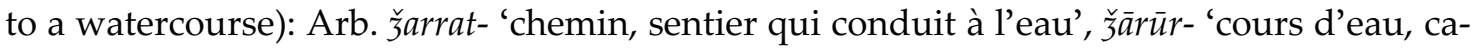
nal' (BK 1 272; cf. క̌ry 'run, flow' ibid. 284), Hrs. gerō 'run (blood, water)', Mhr. gerō 'to pass', (JH 41), (?) Soq. le-ger 'à travers' (cf. DRS 191-2, where these forms are united with others, hardly related, like 'rumination', 'rond', 'tirer' or 'soumettre').

$\square$ < Afras. *gaw/yr- 'walk, run, come and go' (ADB): Brb. *gVwVr- 'to walk': Nefusa, Senhadja ugur, Rif uḡur, Mzab ǐ̌ur (also 'flow'), Shawiya ugir, etc.; Chad. * $g V r$ - 'to go, come, run' (cf. Stolb. 2011 \#674): W.: Dera gur- 'come out', C.: Tera gīri 'return', Logone gár- 'go into', Banana gwara 'follow', E.: Somrai gàr 'come', E. Dangla ógíré 'go by', Nanchere gúr, Dormo geré, Kaba gó-gira, Mubi ygira 'to run'; Cush. N.: Beja agir 'to return', E.: (?) LEC: Oromo gora 'turn off (towards)', HEC: Hadiya geer 'run'.

(3) Ugr. $n t b(-t) / /$ glossed 'path, way' in DUL 651. Restrictedly attested, with very limited attestation in other Sem. as well: Hbr. nātìb 'pathway' (poet.), natībā, Jud. natībat- 'path' (HALOT 732; the Jud. form seems a borrowing from $\mathrm{Hbr}$.).

$\square \quad$ There are curious parallels (or look-alikes) in Chad. W: Mangas nadap, Kir ladààp, Jimi tàboo, Zeem topài, Dokshi tuup, Tule tò̀bò, C.: Fali-Kiria ladāp 'road', E.: Migama tèbbò 'walk', probably implying Common Chad. *n/la-tVb- 'road' (ADB).

(4) Hbr. däräk; Pho. drk // < Sem. *drk '(quickly) follow/tread a path, walk': Akk darāku 'to follow (?)', darku, derku 'following, later' (CDA 56-7), Hbr. drk 'to tread, travel', Pho., Syr., Mnd. drk 'to walk', Old Arm. drk 'to walk to, enter', Arb. drk 'attain, reach, come up with' (Lane 833), Sab. h-drk 'pursue, catch up with', (?) Gez. daraka 'be well-trodden', madrak 'doorway, etc.' (cf. LGz 142, HALOT 231-2, DRS 313-14), 31 Gur. (tä)drakätä 'hurry, rush' (LGur 220), Mhr. darōk 'come quickly to help' (JM 73), Jib. dórók 'to rescue' (JJ 41).

- Without Afras. parallels (not taking into account a casual W. Chad. one: Diri dirki 'road'); interestingly, although inexplicably, has partial similarity, perhaps fortuitous, to (1) Afras. *da(H)r- 'way, road' (ADB): Sem.: Arb. darar- 'the right course or direction of a road' (Lane 864; unless < $d r r$ 'to flow, stream abundantly' ibid. 862; cf. DRS 319); W. Chad. *dVHVr*dVrVH- 'road' (a widely spread term); E. Cush.: Yaaku dar 'way, road'; (2) Sem. *darag'path': Akk. daragg-, Arb. daraž- (etc. - cf. DRS 308); (3) (?) Afras. *darb- 'road' (see \#7).

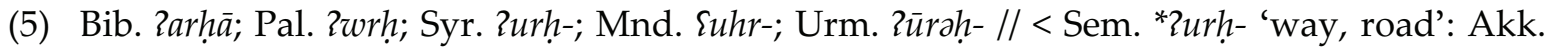
urhu 'way', Hbr. 2ōrah 'way' (rare), Soq. Rérah 'come, arrive'. Reconstructed as *urh- in DRS 32 (omitting 2-, misprint?), where Gez. marha 'montrer le chemin' is quoted with a question mark (v. LGz. 358 with cognates in other Eth.), pointing, unless there has been a scribe error, to *mrh, not * $m r h$; since the comparison seems valid, Sem. * $2 u r h$ - is to be re-

\footnotetext{
${ }^{31}$ In all these sources, especially in DRS, several more forms meaning 'power' or 'be hard, cruel' or 'press, oppress' are quoted, with a non-trivial semantic shift; they certainly do not represent the basic meaning and should perhaps be attributed to a homonymous Sem. root.
} 
constructed rather than * $2 u r h$ - (the semantic connection with Sab. $2 r h$ 'affair, matter, undertaking' SD 7, compared by some authors, is far from evident). ${ }^{32}$

(6) Qur. țarīk-; Leb. țarīi; Mec. țariyg; Mlt. tri̊ // The coincidence with țārik- 'étoile du matin' < Sem. *tt/tarVk- 'night luminary' (v. MOON No. 5) is probably not accidental (cf. țrk 'venir de nuit; faire une sortie de nuit, etc.' BK 2 75). If so, the original meaning is to be reconstucted as something like 'road used in the night time'. Cf., however, Akk. (SB) tarqu path' (quoted in CAD $d 108$ as a variant of daraggu), which, if it reflects phonetic reality, can be < *tark- due to incompatibility of two emphatic radicals in Akk.; otherwise, Arb. țarikk- can be $<{ }^{*}$ tarik-, with assimilation.

(7) Leb. darab (syn.) // Class. Arb. darb- (acc. to Lane, not a word of Arabic origin) ${ }^{33}$ 'any place of entrance, narrow pass, gate, by-street (> street)' (Lane 866-7), Syr darb- 'road, way'.

$\square \quad$ Possible Afras. parallels (ADB): Brb. *-barid (metathesis?) 'road': Ahaggar $a$-barid, Ghat $a$ barid, Ghadames a-brìd, Izdeg, Seghrushen, Mzab a-brid, Shawiya, Qabyle a-brid, Nefusa brid, etc. (compared in Bla Om 68.4 with disparate Omot., Cush. and Chad. terms, which are, furthermore, not cognate with each other) and C. Chad.: Logone dárbà (< Arab?), Buduma turbo 'road'; Cush. E.: (?) Oromo darabaa 'enclosure' (if it fits semantically; N.: Beja darib, C.: Bilin därib, E.: Saho, Afar darib 'road' must be Arabisms).

(8) Sab. $m s_{1} b / /$ also 'way, watercourse' (SD 122) < $s_{1} b$ ' 'to carry out an undertaking (e.g. military expedition, journey, etc.)' < Sem. ${ }^{*} s b ? \sim{ }^{*} s b s b \sim{ }^{*} s b b$ 'walk, go, come' : Arb. sbsb 'walk slowly', subzat- 'long voyage', ma-sbaz- 'chemin' (BK 1 1040; borrowing of the latter form from Sab. is not to be ruled out), Tgr. šbb 'to come'.

- With parallels in Chad. W.: Diri sàbú- 'to go', Warji sámbà 'come in', Tangale simbe 'meet', C.: Bura šiva 'come to the compound', Hildi sabi 'to exit', Daba sub 'follow', Gude saba 'drive away', E.: Somrai sàba 'walk (n.)' (Stol 2009 \#39; ADB).

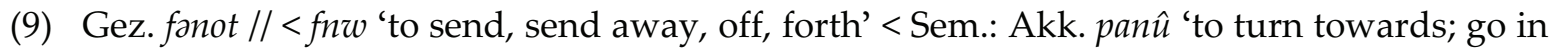
front', Hbr. pānā 'to turn to one side, head in a particular direction' (HALOT 937), Arb. fnn 'to drive (camels)', Tgr. fäna 'to depart', Soq. fini 'go forward', etc. (v. LGz 163).

(10) Gez. ma-ngad (syn.); Tna. mä-gädd-i; Amh. mä-ngäd // < Eth. *nagada 'go on a journey, travel, trade' (LGz 390-91, LGur. 453); if < *na-gad-, probably related to Arb. žāddat- 'grand route, chemin large, route royale' (BK 1 261; unless < ždd 'ê. considérable, respectable' ibid. 259), cf. also Sab. gwd 'swift riding beast' (SD 51).

- Cf. W. Chad.: Bade àgdadù 'ferry across', Duwai àgdo 'ford a river' (in St. 2011 \#492a); E. Cush.: Afar gíddā (RAf; gìta PH), LEC: Somali žid (< * gid-) 'road'; N. Omot.: Wolaita, Kullo ged-iya 'road' (all these forms may be loans from Arb. 亏̌ăddat-, though the difference in vocalism is notable). Cf. also Chad. W.: Hausa gúdù 'flee, run away', C.: Mbuko gad, Muy gudu-gudu 'running' (cf. ngaḍ 'go back'), E.: Sokoro géde 'run, escape', Ubi gèdín, Mawa gadan, W. Dangla gádé, Bidiyo gaḍ 'run’ (St. 2011 \#479). Cf. ADB.

(11) Tgr. gäbäy // (LH 585). Most likely, a semantic shift (cf. the same shift in a reverse direction in Egyp. w’-t 'road, side' below) from gäbo 'side' (ibid. 582) < Sem.: Syr. gabb-, Arb. క̌anb-, Mhr. ganb 'side' (v. SED I No. 85 * $g a(n) b$ - 'side; beside; back; body').

32 To which probably belongs Arb. rwh 'aller, s'en aller, partir, s'eloigner', whose other meaning 'faire quelque chose le soir; voyager le soir' (BK 1 945) may then be due to contamination with the main semantics of that Arb. root, namely 'evening, night' = 'time of (pleasant) wind, breeze' (cf. rwh 'to be a cool and pleasant day because of the wind' quoted in HALOT 1196 after Lane), or 'time of (easy) breathing (after a hot day)' < Sem. *raw/yh- '(pleasant) wind, breeze, (easy) breathing, rest', all of these meanings being distributed among various Sem. languages (cf. ibid.).

${ }^{33}$ If Lane is right, this is a borrowing from Syr., and the Leb. term should be eliminated from scoring. 
$\square$ < Afras. * $g a b$ - 'side, beside, nearby, on the other side': Egyp. (Westcar) gb? 'side of a room'; Chad. W.: Hausa gàba 'across, on the other side of', Dwot gáap 'side', C.: Higi-Baza góbio, Musgu gubbi, gobi, Masa gob 'nearby'; Cush. N.: Beja gäb, geb 'side', geb 'by, near', C.: Bilin gäba 'side (of body)', Khamir gaba 'side', E.: Afar gabbe 'side (of back)', LEC.: Konso, Gidole kapa (<*gab-) 'next to, near, beside', HEC: Burji gáb-a, Dullay: Harso, Dihina kapa (< * gab-) 'side' (v. ADB, EDE I 223, Bla. Review 501).

(11) Arg. hema, həyəma; Cha. ema // < S. Eth. *haym-, likely related to Arb. hmy 'errer çà et là, errer à l'aventure (se dit d'un troupeau)' (BK 2 1450); yahmā? - 'desert sans aucune signe à l'aide duquel un voyageur puisse s'orienter et où il périt facilement' (ibid. 1637).

- Very likely < Afras. *haym- 'walk, come and go' (ADB): Egyp. (ME) îhm 'go slowly'; Chad. W.: Karekare yim- 'return', C.: Tera, Ga'anda àyìm-si, Boka yìm-si 'enter', E.: Migama \{òòmò 'go out'; Cush. E.: HEC: Sidamo ham- 'walk', S.: Iraqw -hizim-it- id.; N. Omot.: Wolaita ham-ett-, Zaise, Chara hám-, Kafa ham(m)-, Anfillo ham-, Bworo (h)aam-, Gimirra (Bench) hamu, Dizi (Sheko) (h)am 'walk'.

(12) Sod. moç̌a // According to LGur 672 and LGz 606, < Sem. *wṣ̂? 'go out'.

(13) Hrs. wōrem; Mhr. hürum; Jib. 2orm; Soq. ?órim // Arb. 2irm-, Zarūmat- '(grosse) pierre destinée à indiquer le chemin dans le desert' (BK 126$)<$ Sem. *2u/irm-.

$\square \quad$ With the fossilized suffix $-m$, presumably < Afras. *war- *2iraw- 'road' (ADB; cf. Bla. Om \# 68.3): Egyp. (Pyr.) wi-t 'road; street; side' (Copt. *wāziy-at Vyc. 231); Chad. *2ar- *war'road': W.: Mupun ár(è), Sura ár, Angas ar, Ankwe war, Kulere Ráraw, E.: Bidiya Róorà; Kajakse irí, Mawa or 'road'; Cush. E.: HEC: Darasa ora 'road', S.: Iraqw irwā, Alagwa, Gorowa uruwa 'path, way'; N. Omot.: Kafa wore-tō 'way, street', Mocha wora-to, Bworo wééra 'road'. ${ }^{34}$

$\diamond \quad$ Gaf. mäyä is considered a loan from Oromo meya id. in LGaf 218 (but not in LGur 441,

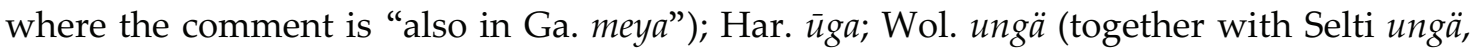
Zway ūngä) 'road, way' are, according to LGur 60, "from Cushitic" (what most Afrasianists, including the present author, now call Omotic): Haruro, Wolaita ogee, Badditu ogge, Janjero wugnā.

$\rightarrow$ No common Semitic.

\section{ROOT}

(1) Akk. šuršu; Ugr. šrš; Hbr. šōräš; Pho. šř̌; Bib. šōrēšs; Pal. šrš, Syr. šerš-; Mnd. širš-; Leb. širaš; Gez. ŝrww; Tna. sur; Amh. sar; Arg. šarit, sar; Gaf. sar; Sod. sar; Har. sar; Wol. sar; Cha. äsar // $<$ Sem. ${ }^{*} \hat{S}_{x} V r \check{s}^{-}\left(\operatorname{dissim} .<{ }^{*} \hat{s}_{x} V r \hat{S}_{x} V r-?\right)^{35} \sim{ }^{*} \hat{S} u r-.36$

$\square \quad$ Cf. the main common Chad. term for 'root' * $\hat{c} V H V r V \sim{ }^{*} \hat{c} V r V H V$ (reconstructed in a different conventional notation in St. 2011 \#287), likely related to the Sem. one, but not without problems in correspondences (cf. ibid. p. 11). Cf. also Proto-Agaw (C. Cush.) *sar- id., which, according to CDA 116, "clearly looks like a borrowing from EthSem".

${ }^{34}$ Cf. EDE I 54: Egyp. (translated as 'way'), W. and C. Chad., Gorowa. Cf. Nostratic *2ur(H)V 'road'.

${ }^{35}$ For ${ }^{*} \hat{s}_{x}$ see footnote 16 above.

${ }^{36}$ An interesting, if controversial, case is the reflexation of this root in Class. Arb.: on the one hand, there is širš- 'root', quoted after Dozy in LGz 535 with the comment "does not give the impression of being an original Arabic root" (a borrowing from Syr.?); on the other hand, there are šaras- 'plante à épines' (BK 1 1214) and širs'small, thorny trees; growing in depressed tracts, and in the deserts' (Lane 1532), both quoted by Leslau (LGz 535) after Schwally, who connects these terms with Hbr. šōräš, assuming the basic meaning to be 'knotty, gnarled' > 'root'. The comparison seems valid, but the explanation may be different: many desert thorny plants have markedly long roots and could be named after this feature. 


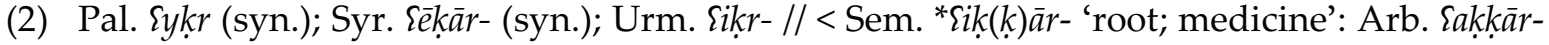
'simple, racine, plante aromatique', Soq. 2ekre 'shoot, sprout', etc. (v. in SED I No. 20 comment on p. 22).

(3) Qur. 2așl- // also 'the lower part of a thing (bottom or foot)', 2șl 'have root or foundation, grow and become firm in its root (tree), etc.' (Lane 64) most likely < Sem. *2/wṣl 'join together, be firmly rooted, be linked with', presumably having evolved into terms with such diverse meanings as *wașil- 'joint, articulation' (SED I 289) and *2ași/al- '(noble) origin' (cf. DRS 30).

$\square \quad$ Cf. a few possible, though scarce, parallels in Chad. * $c$ Vl- 'string' (St. 2009 \#747): W.: Angas sàl 'tree sp., strings are made of fibre of its bark', Bolewa coli 'rope', C.: Mwulien saalu id.

(4) Mec. Sirk; Mlt. (gh)eru2; Hrs. 2ark; Mhr. 2ark; Jib. Sark // in Hrs. and Mhr. also 'artery, sinew, nerve' < Sem. *Ea/irk- 'tendon, muscle, vein, nerf; root': Arb. Sirk- 'veine (dans le corps des animaux et dans les végétaux)', Tgr. Säräk 'tendon, nerf', etc. (v. in SED I No. 20). Probably related, with metathesis, to * $\{i k(k) \bar{a} r-($ No. 2$)$ on the pre-Proto-Sem. level.

(5) Mec. כ̌izir (syn.) // Class. Arb. క̌azar- 'carrot; a certain root, which is eaten' (Lane 419), Syr. gezār- 'radish', Mnd. gizar 'carrot' (DRS 111 2) < Arm.-Arb. *gizar- 'root vegetable' (or a chain of borrowings from Persian, cf. Brock. 113, in which case Mec. క̌izir is to be eliminated from the scoring).

(6) Tgr. kard // I have not been able to find any parallels whatsoever.

(7) Jib. ŝíroh (syn.); Soq. sérah // Soq. also ŝeráh-hiníten (pl.) 'jet, rejeton' (LS 434). More likely related to than borrowed from Arb. šarh- 'racine (de toute chose); produi annuel de chameaux en petits; postérité, enfants', šrh 'grandir; av. grandi (jeune homme), pousser (dent)' (BK 1 1213). The basic meaning of this MSA-Arb. term appears to be 'root shooting out sprouts, suckers; to grow from the root'; 37 formally it is different from Sem. ${ }^{*} \hat{s}_{x} V r s^{-}$ *Ŝr- $(\# 1)$, unless it acquired ${ }^{*}-h$ due to some undetected contamination (no matter how tempting it could be to relate the two roots.). ${ }^{38}$

$\square \quad$ Cf. C. Chad.: Biu-Mandara *şəhəray 'root' (different notation in St. 2011 \#287). Note that if ${ }^{*} H$ in Chad. ${ }^{*} \hat{c} V H V r V \sim{ }^{*} \hat{c} V r V H V(\# 1)$ can reflect ${ }^{*} h$, it may be compared to this root instead of Sem. ${ }^{*} \hat{S}_{x} V r \check{s}-\sim{ }^{*} \hat{S} u r-$.

(8) Jib. (syn.) żéd // also 'vein, artery, nerve, sinew' (JJ 70) < Sem. *gīd-'sinew, nerve' (SED I No. 72).

$\square \quad$ Cf. N. Cush.: Beja gadấm 'root'.

$\diamond \quad$ No term in Sab.

$\rightarrow$ Common North and West Semitic * $\hat{s}_{x} V r \check{s}-\sim{ }^{*} \hat{s} u r-(\# 1)$.

Common South and West Semitic (Arb.) * \{a/irk- (\#5)

\section{ROUND}

(1) Akk. garru // < Sem. * gar(gVr)-: Arb. ̌̌ř̌̌ 'tourner en cercle (p. ex., un bague trop grand pour le doigt)' (BK 274), Gez. 2an-gargara 'to wallow, revolve, roll, spin, drive round, etc.', nagargar 'rolling, spinning, epilepsy', Tgr. 2angärgärä 'to roll, wallow', etc. (LGz 202).

$\square$ < Afras. * $g V r(g V r)$-: Chad. * $g V(V w) r$ - 'round; to roll' (St. 2011 \#710): W.: Hausa gárà 'roll any circular object', Ngas gzwaar, Guruntum ygòori 'round', gwoori 'circle', C.: Mada ygwààr 'round', E.: Sokoro gúgergúger 'turn around', Birgit gèrgèrí 'se retourner', etc.; E. Cush.:

${ }^{37}$ For the semantic shift cf. in No. 2 Soq. 2ekre 'shoot, sprout' < Sem. * $\{i k(k) \bar{a} r-$ 'root'.

${ }^{38}$ Cf. SED I No. 268 comment on p. 240, where Soq. sérah is "likely < * $\hat{r} r$ ", which is wrong in the light of Jib. and Arb. cognates). 
Saho gur, gargar 'to roll' (LGz 202; Leslau also compares Somali girāngir 'wheel'), (?) Yaaku -gorgorsi? (<*-gorgor-si? -si is not clear) 'round'; N. Omot.: Bworo gúura id. (ADB).

(2) Hbr. $\{\bar{a} g \bar{l}$; Soq. gálhel // I prefer to treat the Soq. term, which has no visible direct parallels, ${ }^{39}$ as the result of a metathesis in Sem. ${ }^{*} \delta g l$ (which, on the contrary, should rather be scored on the Semitic level differently from Aram. ${ }^{*} g l l<$ Sem. ${ }^{*} g^{w} V l V l-\# 3$, to which it is

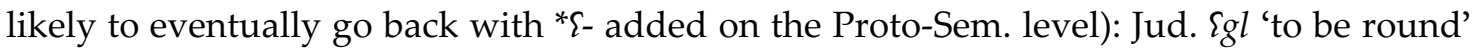
(Ja 1041), Syr. Igl (pa.) 'volvit' (Brock 510), Gez. Sagala 'to surround with a wall, etc.' (LGz 59), Tgr. \&äggälä 'to put in a circle' (LH 487).

(3) Syr. galīl-; Urm. galūl- // Sem. * $g^{w} V l V l-:$ Akk. galālu, Hbr. gll 'to roll', Arb. ̌̌wl 'aller, tourner, voltiger en circle' (BK 1 358), žullat-, žallat-, ̌̌illat- 'boule de fiente' (ibid. 308), Tgr. gälälä, Amh. g gällälä 'tournoyer' (DRS 125), etc.

$\square$ < Afras. * $g^{w}$ VlVl- 'round' (ADB; cf. EDE III 816-20): Brb.: Ahaggar ḡalall-at, Ayr galall-at 'to be round', Adghaq a-g'ilallaw-an 'round', etc.; Chad. W.: Hausa gùlūlì 'ball (of earth, cotton)', Ngas gwaal 'small lumps or balls', Bolewa golgol 'small and round', C.: Mofu

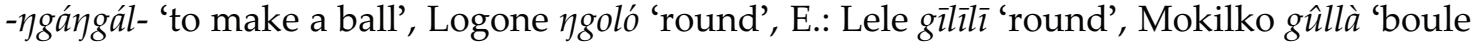
(de farine)' (St. 2011 \# 597, 597b). ${ }^{40}$

(4) Mnd. kulul- // < Sem. * $k^{w} V l V l-:$ Arb. 2iklīl- 'chair autour de la naissance des ongles; nuage qui semble entouré d'une légère enveloppe' (BK 2 919; also 'crown', presumably from Arm. from Akk. kalìlu, which is, anyway, likely related to this root - v. LGz 283), Gez. kallala 'to surround, encircle', 2ank ${ }^{w}$ alala 'to roll, etc.', Tgr. källa 'to go around', kälkäla 'encircle', Tna. $k^{w}$ ällälä 'to go around', Amh. källälä 'surround, crown' (LGz 283).

$\square$ < Afras. ${ }^{*} k^{w} V l-:$ Chad. W.: Angas kool 'crooked, not straight', Bolewa kòoloki 'hoe handle with curved end', Ngamo kùlè 'bowleggedness', C.: Mulwi kálà 'circular', E.: Kajaksa koolo 'hump', etc. (St. 2011 \#191); (?) Cush. N.: Beja kwalál 'round' (< Eth.?), C.: Bilin kaläl, E.: Saho kulel 'circle' (both < Eth., acc. to LGz 283), LEC: Oromo kallee 'egg' (ADB).

(5) Leb. m-dawar; Mec. mu-dawwar; Hrs. me-dawwer; Mhr. ma-dáwwar // Because of the diversity of non-derived forms, hardly an Arabism in MSA (though Arb. influence in the forms with $m$ - cannot be ruled out): Hrs. dōr 'to go round', dawr 'turn' (JH 26), Mhr. dawr 'turn', $d \bar{c} r$ 'to wander around' (JM 76), Jib. $d \bar{\varepsilon} r$ 'to wander around' (JJ 42) < Sem. *dwr: Ugr. $d r$ 'to surround (?)', $d r$ 'circle (of relatives and friends); cycle, generation' (DUL 279), Hbr. dūr (hapax) 'to stack in circles' (HALOT 217), Arb. dwr 'aller tout autour, tourner' (BK 1 747), dārat- 'cercle; halo' (ibid. 748), Tgr. dorä 'go around', dawar 'circle' (LH 536; an Arabism?).

- With scarce parallels in E. Chad.: Kabalai wàd̀̀rà 'turn', Migama kà-dãrdìrò 'turn around' and C. Cush.: Aungi dardar 'turn, rotate' (ADB).

(6) Gez. kabb; Tna. kabib; Tgr. käbib, kabub; Amh. kabb; Sod. kabb; Wol. kub; Cha. kab // < Sem.: Hbr. pB. kirkeb 'to encircle' (with secondary insertion of $-r$-), Arb. kubbat- 'ball, ball of thread, lump', kabkāb- 'ball of thread' (LGz 273 after Dozy), kbb II 'to form into a ball' (ibid.), etc.

(7) Tna. (syn.) 2an-kablal // < N. Eth.: Tna. $k^{w}$ äblälä 'to stroll about', Tgr. (ta)käbläla 'to roll while falling' (LGz 274); probably connected with Sem. *kabl- 'hook, ring, shackle, fetter' (v. LGz 274); otherwise $<{ }^{*} k V b-l$ - with a root extention $-l$ (v. Mil. RE 115-118)..

(8) Har. dulālu // andōläla 'make round', with reduction of $-b$ - to vowel < Eth. *dbll *dblbl 'be round' (LGur 196) < Sem. *dVbVl- 'round': Ugr. dblt, Hbr. dabēlā, Syr. dabalt-, Hrs. debelet

\footnotetext{
${ }^{39}$ A formally impeccable parallel, however, may be Arb. ̌̌ $u\{(a) l-$ 'scarabée, fouille-merde' (BK 1301 ); dung beetles are noted for rolling dung into spherical balls (cf. Arb. ̌̌u/alillat- 'boule de fiente' in \#3).

${ }^{40}$ Probably further related are Afras. ${ }^{*} g\left({ }^{w}\right) V l$ - 'egg' and/or * $g V l(g V l)$ - 'head; skull' (ADB; for Chad. * $g V l-$ 'skull' see St. 2011 \#597a).
} 
'cake of figs' (cf. DRS 209), Arb. dublat- 'boulette, tout ce qui est formé en boule' (BK 1 668).

$\square \quad$ Most likely, related to Egyp. (Pyr) $d b n$ 'be round', (OK) 'ring, round box' (if $-n<*$ - $l$ ). There is also N. Cush.: Beja debāl 'round' (ADB), looking quite like an Ethiopism, although I have been unable to detect an exactly similar-looking source term in Eth.

(9) Jib. halkét // < Sem. (less likely an Arabism in MSA): Mhr. hōlak 'to circle in the air', herwkāt 'circle, ring', Soq. hálkah 'hook, ear-ring' (JM 178), Arb. halkat- 'ring of metal', hlk II 'to draw a circle', Gez. halaka 'to become, grow round', etc. (LGz 230). This Sem. root is probably related to Sem. *halk- 'Adam's apple, throat' (SED I No. 117).

$\diamond \quad$ Mlt. tont very likely < Ital. tondo. No term in Ugr., Pho., Bib., Pal., Qur., Sab., Arg. and Gaf.

$\rightarrow$ Common South and West Semitic * Eagl- * gasl- (\# 2).

70. SAND

(1) Akk. bāṣ̦u // < Sem. *bVṣ̂-: Hbr. bōṣ 'silt', biș̣̦ā 'waterlogged ground', Pal. bṣyn 'marsh', Arb. baddat- 'waterlogged ground' (HALOT 147 after Bauer; neither in Lane nor in BK), bdd 'have little water (well, source)' (Lane 213).

(2) Hbr. ḥōl; Pal. ḥāl; Syr. ḥāl-; Mnd. hal- // < Sem. *hawwl-: Arb. hāal- 'terre mêlée de sable, boue noire, vase' (DRS 846).

(3) Qur. raml-; Leb. ramal; Mec. ramal; Mlt. rāmel // Perceived as an isolated Arb. term; cf., however, Sab. rml 'building sand?' (SD 117), Gez. ramal 'sand' (acc. to LGz 471, < Arb.). There are also Hrs. remlét, Mhr. ramlēt, Jib. $r \bar{\varepsilon} l$ 'sand', apparently Arabisms, if not for a nuance that causes certain doubts: the apparently denominal verbs in MSA are Mhr. rátmal 'to be covered with sand', Jib. rōl 'to roll in the dust, to lie in wait' and Soq. rémol 'to lie hidden, crouch down' (JM 327; 's'étendre' in LS 401 with the following comment: "est peut-être un dénominatif de ramal- 'sable'; le verbe aurait le sens 'se coucher sur le sable" "; for the semantic connection see No. 9 below). The nuance is that there is no corresponding noun meaning 'sand' in Soq., whereas the verb in Soq. is obviously connected with at least the one in Jib. This is difficult to explain other than by suspecting that the former is an inherited word, which may cast some new light on the status of the MSA noun.

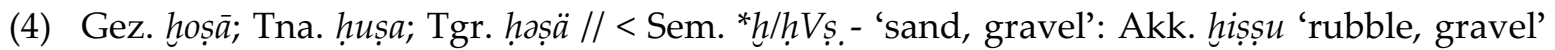

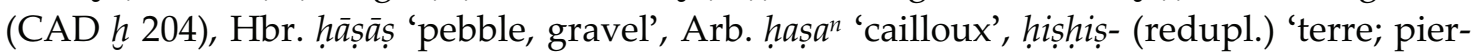
res', etc. (v. LGz 266, DRS 908).

口 Perhaps < Afras. * quas/ç-41 'hard sand' (ADB): Chad. W.: Hausa kásá 'earth, soil', Boghom kâas 'earth', C: Malgwa késa 'sand', Cuvok kóskò 'sable aggloméré asses dur', etc., E.: Nanchere kasa 'terre', W. Dangla kòskò 'hard sand' (St. 2011 \#328); C. Cush: Bilin kuš̌a 'sand' (App. CDA 118); Omot. N.: Dokka kạ̣̌e, Kafa ḳaço, Gimirra (She) kạc, Dizi (Nayi) ḳaṣa 'sand', Mao (Hozo) keci 'earth', S.: Galila kaç ‘sand' (v. Bla. Om \# 71.1., Bnd. Om.).

(5) Amh. aššäzwa; Arg. hašawa; Sod. ašawa; Wol. ašawa; Cha. ašawa; Jib. ḥáši // < Sem. *hašw/y-: Arb. hisan 'puit creusé dans un terrain sablonneux; sol dur recouvert de sable' (BK 1 429; overlooked both in LGur 102 and DRS 937), Tna ḥašäwa 'sand' (LGur 102), Hrs. ḥōhi 'ground', Soq. hóhi 'ground' (JJ 118; both < *hošy-); as for Jib. háši, it is glossed as 'soil' in JJ 118 , but translated as 'sand' in cháši kódós 'the sand piled up' and ekdés háási 'covered with sand' in JJ 126, while also given in the entry for 'sand, soil' in Nak. \#780.

$\square \quad$ < Afras. *has(a)y-(ADB): Chad. W.: Ankwe hés, Tala hēs, Fyer hós (and several other forms without $h$-, perhaps representing a different root), C.: Ngwahyi hašì 'sand'; Cush. N.: Beja

${ }^{41}$ The hypothetic ${ }^{*} \dot{q}$ - yields Sem. and Egyp. ${ }^{*} h$ vs. ${ }^{*} k$ in other Afras. branches. 
híssay, íssa (and hāš, which may be an Ethiopism), S.: Iraqw hasam (< *has-am-; v. MQK 49), Qwadza hasin-ko 'sand'.

(6) Har. šiḩšēra // < Mod. Eth.: Zway šəršsra id., Amh. šäräšär 'kind of red earth', Tgr. šäšär 'small stone' (LGur 586). No observable cognates in Sem.

- Cf. also in Cush. C.: Bilin šašara, E.: HEC: Hadiya šaššara 'sand' (LGur 586).

(7) Har. sēlāt (syn.) // Related to (or borrowed from?) Arb. sihlat- 'gros sable que l'eau charrie'

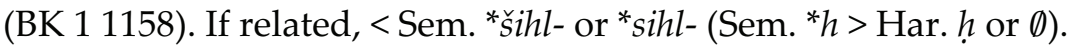

口 < Afras. *sihl- 'sand': Chad. *sil- (in St. 2011 \#150, reconstructed as *sVl-, but *-i- seems natural): W.: Tsagu sílíye 'fine sand', C.: Podoko sasála 'sable', Malgwa šílíye 'grainy sand, gravel', E.: Toram šil 'dune'; cf. also C. ${ }^{*} S V \gamma V l$ - 'sand' (ibid.; * $-\gamma$ - points to *-h-?): Glavda sáfàla, Cinene sayala, Mandara šilì, Nakatsa sìfle (cf. also Bidiya Risín-silaalà 'sable alluvial' in Jg. Bid., where Zisin is 'sand'); (?) E. Cush.: Afar sahlyta 'sand' (-h- is expected to render * $h$, not *h); N. Omot.: Male māšala (<ma-šal-?), Dache siliimo, Zergulla silemo (< sil-em-?) 'sand' (ADB).

(8) Hrs. bațeh (also 'soil'), Mhr. bațh; Jib. buṭ (syn.) // Soq. mbéțah 'coteau' (LS 85). A borrowing from Arb. (cf. Hụ̂r. bațha 'gros sable', Dof. bețâh 'Sandtal' LS 85, Class. Arb. bațhat- 'sol déprimé comme le lit d'un torrent à sec couvert des cailloux' BK 1 135) is unlikely in view of the hardly unrelated Soq. term with a different but compatible meaning and Jib. bóttah 'to lie down on the belly on the soil' (JJ 30) < Sem. *bth 'to lie down (on the sand?); to spread, extend (of sand?)' (v. No. 3 for semantic connections and LIE No. 14).

(9) Soq. šéme 42 // The only cognate in Sem. that I was able to unearth is Arb. šiyām- 'dust or earth, soft or uncompact earth' (Lane 1635). Arb. š vs. Soq š implies the reconstruction of the first radical as ${ }^{*} \hat{s}_{x^{-}}<$Afras. ${ }^{*} \hat{s}^{-}$.

$\square \quad$ Cf. scarce possible parallels in Chad. (implying, however, Afras. ${ }^{*} \hat{c}^{-}$, not ${ }^{*} \hat{s}^{-}$, cf. St. 2007 8): C.: Gisiga ŝimiyew 'sand', E.: Mokilko sáàmè 'uncultivated land, fallow'; Omot. N.: Chara ámša, S.: Hamar šami, Ari (Bako) šaami 'sand'.

$\diamond \quad$ Urm. sìl- is < Turkish (a curious chance coincidence with No. 7 above). No term in Ugr., Pho., Bib., Qur., Sab. and Gaf.

$\rightarrow$ Common South and West Semitic *hašw/y- (\#5).

(Perhaps also Common South and West Semilitic *raml- \#3).

71. SAY

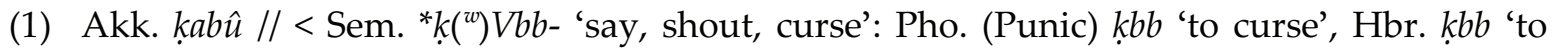
curse, enchant' (HALOT 1060), Arb. $k b b$ 'faire du tapage, du vacarme (se dit de ceux qui sont en rixe)' (BK 2 656; not compared in HALOT), k.kkb 'utter a sound' (both compared in LGur 468), (?) Tgr. käbbä 'despise, abuse, ignore' (compared in HALOT, but not in LGur.), Amh. $k^{w} \ddot{a} b a$ 'talkative', Chaha $k^{w} a b$ amänä, Eža, Muher $k^{w} a b$ amännä 'produce a sound' (LGur 468).

With some parallels in Afras. (ADB): Chad. W. *kab- (<*kab-): Tangale kebi 'to name', Polchi káḅ 'to answer', E.: Ndam kába 'to talk'; Cush. E.: LEC: Somali qabqab- 'shout' (n.); (?) N. Omot.: Bworo kewa 'talk’ (Bnd. Om. 172, possibly < *kVb-, see ibid. 184-5).

(2) Ugr. rgm // also 'tell, announce, communicate, inform, answer' (DUL 732) < Sem. * rgm 'to blame, procecute, curse' (on the connection with Sem. ${ }^{*} \mathrm{rgm}$ 'to stone' see Maizel 201): Akk. ragāmu 'to shout, prosecute, raise claim' (CDA 295), Arb. r亏̌m 'to curse, abuse', Gez. ragama 'to curse, insult, execrate, excomunicate', etc. (v. LGz 465).

${ }^{42}$ According to Kogan MS (quoting two more synonyms absent in LA: taḥk and șákere, to none of which I could find parallels in the continental MSA); cf. šimih 'sable de mer' (LS 418), štmi 'sand' (the only Soq. term for 'sand' adduced in Nac. \#780). 
(3) Hbr. 2mr; Pho. 2mr; Bib. 2mr; Pal. 2mr; Syr. 2mr; Mnd. 2mr; Urm. 2mr // < Sem. *2mr: Arb. $2 m r$ 'ordonner' (BK 1 53), Jib. 2õr 'to order', 2عmr 'matter, order' (JJ 3; unless < Arb.), etc. ${ }^{43}$

(4) Qur. kkwl; Leb. 2āl; Mec. kāal; Mlt. āl // < Sem. *kawol- 'voice’: Ugr. Pho. ḳl, Hbr. ḳōl, Syr. ḳāl-, Mnd. kala 'voice', Gez. kuăl 'voice; saying, speech; word', etc. (LGz 426).

$\square$ < Afras. *kawl-: Chad. * ${ }^{*} V l$ - 'to talk, speech': W.: Angas kwal 'to talk, talking', E.: Tobanga $k w a ́ l$ 'word, languages, tale, talk' and * $k V w V l$ - 'shouting; to call': W.: Kirfi $k^{w}$ alala 'war shouting', Bolewa kèlè 'greeting', Bade koluwà 'shouting', C.: Fali-Kiria kalwa 'shout, scream', Mada kullar 'grand cri', E.: 'to call’: E. Dangla kólé, Bidiya kol, Migama kólló, Jegu kol-, etc., ${ }^{44}$ Cush. E.: Afar -kal- 'think, say', HEC: Oromo qaalii 'word' (likely < Amh.); N. Omot.: Mao (Bambeshi) koli, koli, (Diddesa) kyoli ‘say, speech' (ADB).

(5) Gez. bəhla; Tna. bälä; Tgr. bela; Amh. alä; Arg. ala; Gaf. balä; Sod. baläm; Har. baya; Wol. balä; Cha. baräm // < Sem. *bhl 'to speak, beseech, pray, curse': Akk. båālu, bâlu 'to pray, beseech' (CAD b 2), Arb. bhl 'maudire (se dit de Dieu)', VIII 'implorer, supplier' (BK 1 173), etc., Hrs. behelēt (JH 16), Mhr. behlït, Jib. behlét 'word' (JM 45), etc. (v. LGz 89, DRS 48).

$\square \quad$ With scant plausible parallels in W. Chad. *biHal- (ADB): Mupun byal 'vicious, angry, cruel', Montol bial 'anger', Tangale pule ( $p$ - may render * $b$-) 'to be, become annoyed, angry'.

(6) Hrs. Samōr; Mhr. Samūr; Jib. £õr; Soq. Semor // A difficult case which cannot be immediately equated with Sem. ${ }^{*} 2 m r$ on formal grounds though a semantic contamination is possible. Another meanings in MSA are: Hrs. Sámer 'to mend' (JH 9), Mhr. \&āmōr 'compose, sing poetry', hāmōr 'develop, order, repair' (JM 25), Jib. £ōr 'to order', o£ōr 'repair, build' (JJ 13), Soq.: Sémor 'faire, remplir, mettre dans, porter', corresponding to Arb. Smr 'become many, become in a state of good repair; cultivate, promote; worship, pray' (Lane 2154). The only semantics, from which all these diverse meanings could derive seems to be causing to existence or accomplishment by force of magic speech/formula. ${ }^{45}$

$\diamond \quad$ No term in Sab.

$\rightarrow$ No Common Semitic.

72. SEE

(1) Akk. amāru // < Sem. *2mr 'to see; show, indicate; know' (v. KNOw No. 6).

(2) Ugr. phy // also 'espy, look at', 'know, recognize' and 'visit '(DUL 667). No direct parallels. In DUL 667 tentatively compared with Akk. (w)aph 'to become visible, appear' (CAD a2 201), which does not work, since the Akk. term is cognate with Ugr. yps 'to leave, depart, appear', (N) 'to rise, present oneself' (DUL 972-3), Hbr. yp (hif.) 'to cause

${ }^{43}$ Joined, both in DRS 23-24 and EDE III 32 (with the comment "the semantic shift "to say" vs. "see"... is widely attested"), with *2mr 'see', which I prefer to treat as a separate root, although for at least a few forms it is, indeed, hard to decide from which of the two verbs they are derived - perhaps due to contamination. It should be noted that Sem. *2mr 'to see' has wide Afras. connections (see No. 72 below), while *2mr 'say' seems to have none, implying the shift "see" > "say", which I perceive as neither self-evident nor "widely attested".

${ }^{44}$ In St. 2011 \#192 and 192b., where the Chad. root is compared with Sem. *kwl with the comment: "According to R. Blench, there are some words with initial $k$ - in Fali Kiriya. All other Chadic languages presented in this issue do not distinguish between $\mathrm{Ch}$ *k- and *k-".

${ }^{45}$ A similar semantic phenomenon, likely rooted in the ancient magic mentality, is the famous association in Semitic between "word”, “matter, affair” and "thing”, cf. Hbr. dābār 'word, matter, affair, (some)thing' (HALOT 211); Gez. and other Eth. nagar 'speech, word, affair, matter' (LGz 392); MSA: Hrs. behel-ēt (JH 16), Mhr. behlīt, Jib. behlét 'word' (JM 45) vs. Soq. bíleh < bihl-eh 'chose' (LS 83). 
to shine, to rise, shine forth', etc. (HALOT 424). The only imaginable, if problematic comparison, made in EDE II 488, is with a bunch of Arb. variant roots: $b 2 h$, $2 b h$ 'porter son attention (sur)' (DRS 2 and 40), bh? 'comprendre; s'habituer à qc.' , ${ }^{46}$ wbh 'connaître, faire attention à, avoir soin de' (DRS 484). However, this comparison is justified only if one accepts the debatable Sem. phoneme ${ }^{*} \dot{p}$ (see SED I CV-CXVI), which Takács does not seem to accept.

$\square \quad$ On two series (with ${ }^{*} p$ - and ${ }^{*} b$-) of phonetically and semantically problematic Afras. parallels to both Ugr. and Arb. verbs, see EDE II 487-8.

(3) Ugr. In (syn.) // also 'to look, watch, spy' (DUL 167). A denominative verb from * \{ayn'eye' (v. EYE No. 1 in Mil. 2010).

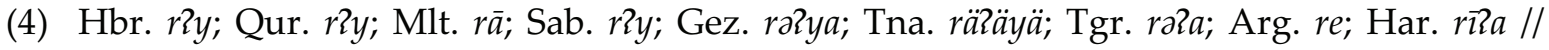
< Sem. *r?y 'to see' (HALOT 1157, LGz 458-9).

$\square$ < Afras. *rayz- *2ayr- 'see': Chad. *ray/2- *2ayr- 'eye' (St. 2005 \#651 and ADB): W.: Kulere $r \hat{\imath}(h)$, Jimi yára, Polchi yir, Zaar ȳ̄r, Sayanchi yīr, Fyer yè̀r, etc., C.: Zeghwana ire, Gisiga re, Musgoy riya, Gidar arạ, Munjuk aray, Mbara rée 'face, eyes', Banana irà, Zime-Batna zír (rázá 'stare at': note metathesis and -2-), etc., E.: Mubi ír-ín (pl. ar-an), Mokilko ?êr-sá (-sa is a body-part suffix); Cush. N.: Beja iray 'see', S. *2ar- 'see': Iraqw ara, Alagwa ar-, Burunge $\operatorname{ar}$-im- (ADB).

(5) Pho. hִzy;7 Bib. ḩzy; Syr. ḩzy; Mnd. hza; Urm. h.zy; Amh. ayyä; Arg. hanža; Gaf. ažžä; Sod. ažžäm; Wol. anže; Cha. až/šäm // < Sem. *hzy 'to see'. In DRS 854 (and, similarly, in HALOT 301), this entry includes Arb. hzy 'partir les oiseaux (pour tirer des augures de leur vol), tirer des augures', hāazin 'voyant (qui prédit l'avenir), conaisseur', whose semantic connections with 'see' are less evident than those of Arb. hzz III 'contrôler, examiner, scruter avec le plus grand soin' (BK 1418 ).

$\square \quad$ Note a single, perhaps accidental, parallel in C. Chad.: Matakam húz- 'regarder' (ADB).

(6) Pal. hmy // < Hbr.-Arm. *hmy 'to see, watch, beware': Hbr. hmy 'see', imp. 'beware!' (HALOT 326), Syr. hmy 'vidit; taeduit eum am; omisit' (Brock. 239) < Sem. *hmy 'to watch, protect': Sab h̆my 'to protect' (SD 69), Arb. ḥmy 'défendre, protéger' (BK 1 497), Mhr ḥomi 'to defend' (JM 182), etc. (see Kog. Ugr.-Can. \#35).

- Cf. Egyp. (Dem.) mh 'see', Copt. *moH- 'to look; appearance' (EDE III 483), perhaps related (not compared with the Sem. root in EDE), with metathesis, to a couple of possible cognates in E. Chad. *HamVy-: Tobanga āmēe 'guard' and Birgit zúm 'see' (ADB).

(7) Leb. šêf; Mec. šâf // Class. Arb. šwf IV 'regarder du haut de...; dominer un objet; avoir peur de qn.', etc., šayfat- 'reconnaissance, détachement de troupes qui observe les mouvements de l'ennemi' (BK 1 1228) < Sem. * ${ }^{*} w w p$ 'look out, observe, protect': Sab. $s_{2} w f$ 'look after, protect, defend' (SD 136), (?) MSA: Hrs. me-šwā̄f 'sight (of a gun)' (LHrs 125, Omani Arb. $m i$-šwwäf ibid.), Mhr. me-ŝwwōf 'back-sight of a rifle' (both probably < Omani Arb.), ma-ŝáwfat 'protected (tabu) person, thing; protection' (JM 387; unless a borrowing from an Arb. dialect, implies the verb * $\hat{s} w f$ 'protect'), Jib. sifft 'front sight of a rifle' (JJ 257).

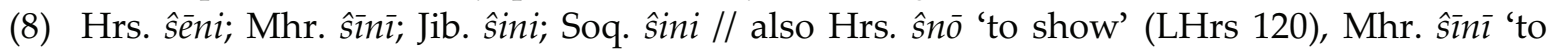
consider' (JM 381), Soq. sénne 'montrer' (LS 431). Cognate with Arb. šsn 'connaître; s'informer; avoir soin; veiller sur quelque chose', etc. (BK 1 1179).

$\square \quad<$ Afras. * $\hat{c} V n \imath / y$ : Egyp. (NE) šnw 'examination, inspection' (compared in EDE I 130 with the MSA verb); (?) Chad. W.: *̂̂Vn-: Chip len gwe 'remember', Dera šèní 'remember, re-

${ }^{46} \mathrm{Ibid} .47$, where it is further compared with Sab. bhit, glossed as 'enter' in SD 27, cf. bhat meaning 'scout, intelligence agent' (ibid.).

${ }^{47}$ Unless borrowed from or influenced by Arm. 


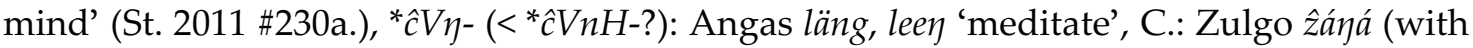
irregular voicing) 'penser, réfléchir' (ibid. \#230b.). ${ }^{48}$

$\rightarrow$ Common West Semitic. ${ }^{*} r y(\# 4)$ and ${ }^{*} h z y(\# 5)$.

73. SEED

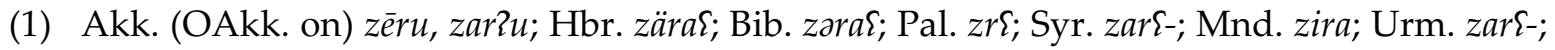
Qur. zark-; Mlt. zerri(gh)a; Gez. zar2, Tna. zär2-i; Tgr. zära2; Amh. zär; Arg. zär; Gaf. zär; Sod. zär; Har. zär; Wol. zär; Cha. zanä // < Sem. *zar反/2-:49 Jud. zaraీ, zark- 'seed', zr反 'to strew, sow' (Ja. 414), Mnd. zra 'to sow, scatter' (DM 170), Arb. zrא 'semer, répandre la semence; ensemencer un champ de quelque graine', zur£- 'semence; céréales sur pied, champ cultivé' (BK 1 124), Gez. zarz/Ia 'to sow, seed, scatter' (LGz 642), Mhr. zūra '(plants) to grow', ha-zrē 'to cultivate', S. Mhr. zarēt 'plantation, cultivated area' (JM 469), Jib. zéras '(plants) to grow', ezóraई 'to plant many seeds', zéraई 'farmer' (JJ 320).

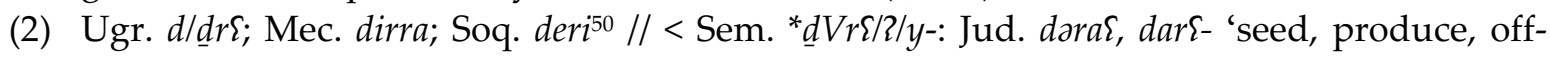
spring' (Ja. 324), Arb. $\underline{d} r$ ' 'ensemencer (la terre)' (BK 1 767), dry/w 'répandre la semence (en semant), semer' (ibid. 771), durat- 'dorra, espèce de millet' (ibid. 772), Sab. m-drrz-t 'sown field, sown ground' (SD, 40)..$^{51}$

$\square$ < Afras. *ร̌ Vr-: (?) Egyp. (Gr., late) $z^{3}$ (if < ${ }^{*} z r$ ) 'Bez. der achtel Arure, acht Aruren Acker' (EG III 411), (Gr.) 'Art Acker' (ibid. 414); Chad. W.: Pero క̌úrà, Guruntum žàažàr 'groundnuts', C.: Malgwa zar-va 'Sesam' (in St. 2009 \#550 in the entry for 'fodder grass'), (?) Munjuk zaraw 'botte de céréales avec des épis; fascicle of cereals with ear' (in St. 2009 \# 550a. in the entry for 'pile of stalks'), (?) Mbuko zaray 'pousser par terre (haricots)', Zulgo zárá 'faire de pousses, long sprouts' (both in St. 2009 \#542 in the entry 'to sprout'), (?) E.: Bidiya zùurì $\left(<^{*} z-\right)$ 'valée favoirable a la culture du petit mil'; Cush. (?) N.: Beja derá? 'seed' (probably an Arabism), C.: Khamtanga zirwa, Khamta zirwä, Kailiña zärwa 'wheat', ${ }^{52}$ E. (all < Eth.?): Saho dara, Afar diriyi 'seed', LEC: Gidole zare 'seed; cultivate', HEC: Hadiya, Qabenna zare-tta, Alaba zari-ta 'seed'; N. Omot. (< Eth. or E. Cush.?): Wolaita zer- 'to spread, to seed', zere-tta, Malo zere-c, Gamu, Dache zere-cci, Gimirra (Bench) zar 'seed', Kachama zeer- 'to sow' (ADB).

(3) Mnd. baz(i)r- (syn.) $)^{53} / /<{ }^{*} b V z r-$ : Hbr. $b z r$ 'to scatter' (otherwise < ${ }^{*} b \underline{d} r$ as in HALOT 118, where it is compared with Arb. $b \underline{d r}$ and Bib. bdr), Frah. bzr 'corn, seed' (HJ 150), Syr. bazr'oleum e semine lini expressum' (Brock. 65), Jud. bzr 'to strew, scatter', bizr- 'seed' (Ja. 154), Pal. bizr-, Arb. ba/izr- 'semences, graines' (BK 1 121; hardly < Arm., in view of several related meanings, including verbal ones). ${ }^{54}$ Cf. Kog. LE \# 73 with a different interpretation. Cf. also LGz 118.

${ }^{48}$ Alternatively, related to C. and E. * $\hat{c} V n$ - 'listen, hear' (ibid. \#230, where it is compared with Mhr. $\hat{s} n y$, with the remark: "NN 230a,b are not necessarily related to N230").

${ }^{49}$ It is difficult to choose whether some of the forms should be related to this root or to * $d V r \varepsilon / 2 / y$ - (\#2 below); ${ }^{*} z$ - is supported by all of the listed Arm. and Arb. forms and MSA data, whereas Akk., Hbr. and all the Eth. forms may as well go back to *dar $\left\{/ 2-\right.$. As for ${ }^{*}-\left\{\right.$ and ${ }^{*}-2$, there is an indiscriminate mess in both variant roots, ${ }^{*} z a r \varepsilon / 2-$ and * $\underline{d} \operatorname{Vr} \delta / 2-$, very likely due to contamination (cf. also Gez. zarawa, zaraya 'scatter' LGz. 644)..

${ }^{50}$ Acc. to Kogan MS, one of two equal synonyms, on par with šáne.

${ }^{51}$ Mhr. daráyyat 'offspring' (JM 81), Jib. darrit 'progeny, offspring' (JJ 47) as well as Mhr. darēt (JM 82) and Jib. dére't 'sorghum, dhurah' (JJ 47) are most likely Arabisms.

${ }^{52}$ Acc. to App. CDA 146, all < ${ }^{*} 3 \ddot{r} r g^{w}-a$, counter to the table of regular correspondeces (ibid. 13), where ${ }^{*} g>$ Khamtanga $g$, not $w$.

${ }^{53}$ Less likely to be an Arabism, in view of Arm. cognates with -z-.

${ }^{54}$ Note Hrs. Mhr. Jib. Soq. bazār 'peppers', marked in JM 61 as Arabisms (from some South Arabic dialect? No term for 'pepper' in Class. Arb. *bzr). 
$\square \quad$ Cf. Chad. W.: Mburku, Jimbin vazar 'seed', Tala bazr 'corn' (probably Arabisms), C.: Daba valuzal (<*buzar?) 'yellow corn', (?) E.: Mokilko búzú 'seed'.

(4) Leb. $b \underline{d} a r / /<$ Sem. * $b a \underline{d} r-:^{55}$ Class. Arb. badr $r$ 'semence', ${ }^{56} b \underline{d} r$ 'semer, répandre pour semer' (BK 1 101), Syr. $b d r$ 'sparsit, dispersit' (Brock. 60), Jud. $b d r$ 'to scatter, strew' (Ja. 141), Mnd. $b d r$ id. (DM 52). Cf. Kog. LE \# 73 with a different interpretation. Cf. also LGz 118.

(5) Har. säñi; Wol. säñ̃ne (unless < Cush., see below); Soq. šáne (syn.) // also 'semence, blé qui est sur les tiges', héne 'semer' (LS 145) < Sem. *šanal/y/n-: Mhr. mo-hnoy 'farm near a town' (JM 159), Jib. mə-šnu? 'garden on the mountain for dhura or beans', ešné 'to have a garden, field' (JJ 263), Akk. (OB, MB, SB) ašnan (asnan) 'grain, cereal (as a generic term)' (in AHw. 82 marked as a loanword; CAD a2 450; <* $a$-šnan-, with prefixed $2 a$ - or metathesis; contra Kog. LE \# 79: “apparently, no Semitic cognates”), Zw. säñi 'seed, crop' (LGur 555). ${ }^{57}$

$\square$ < Afras. * sany- 'seed, grain, cereal' (Mil. Farm. 142, ADB): Egyp. (MK) sn.w 'Opferbrote' (EG IV, 155); Chad. *sin- 'seed, cereal' ( ${ }^{*} V n$ - 'sprout, seed' in St. 2009 \# 300): W.: Tangale sịnị 'sprout, germ' (and Goemai song 'millet', quoted by Stolbova with hesitations), C.: Daba sèsinn, Kola sísîn 'seed', E.: Kera séene 'Negerhirse, petit mil', Saba bi-sinya, Migama bú-sìnì 'seed', W. Dangla sínà 'sorgho',58 Cush. E.: LEC: Somali šuni, Oromo saññii, Dasenech sanne, HEC (probably < Oromo): Darasa sanne, Burji sañnee 'seed'; S. Omot.: Hamar isin 'sorghum'. 59

$\diamond \quad$ Hrs. badr; Mhr. bidar; Jib. bédar, probably Arabisms (note, however, the verbs: Mhr. badōor, Jib. bódór 'to sow, cultivate' JM 44, JJ 23). No term in Pho. (zr\{ is glossed only as 'offspring' Tomb. 96).

$\rightarrow$ Common North and West Semitic ${ }^{*} z \operatorname{ar} / / 2-(\# 1)$.

Common South and West Semitic ${ }^{*} \underline{\operatorname{dV}} \boldsymbol{r} / 2-(\# 2)$ and ${ }^{*}$ šanar/y/n- (\#5). ${ }^{60}$

74. SIT

(1) Akk. wšb; Ugr. ytb, 2ațib; Hbr. yšb; Pho. yšb; Bib. ytb; Pal. ytb; Syr. ytb; Mnd. ytb; Urm. ytb; Sab. $w \underline{t} b / /<$ Sem. * $w \underline{t} b$ 'sit, dwell, live' (HALOT 444, DRS 656). If it is permissible to make a conjecture about this verb's "proto-meaning", I would bet on 'occupying foreign territory or raiding it for women (or ritually imitating this action)', which would account for some most likely related terms (the root with initial ${ }^{*} w$ - and ${ }^{*} \underline{t}$, rare in Sem., is too phonetically unique to represent homonyms) with meanings that are different from 'sit, dwell, live', preserved in various languages: (1) Sab. $w \underline{t} b$ 'sit, reside, settle, occupy' and $t$-w $w b$ 'commit an assault on; ambush' (quoted as two separate entries in SD 165), Arb. watbat'assaut, attaque, agression', wțb V 'faire une invasion injuste sur la proprieté de quelqu'un' (BK 2 1482), (2) Syr. 2awteb 'marry', Gez. Zawsaba 'take a wife, marry', Tna. 2awäsäbä id., Amh. (a)wässäbä 'copulate' (LGz 619; cf. aslo redupl. Gez. sabsaba 'marry off (a son or a daughter in a religious ceremony)' and 'commit a carnal sin' ibid. 485). Cf. DRS 656.

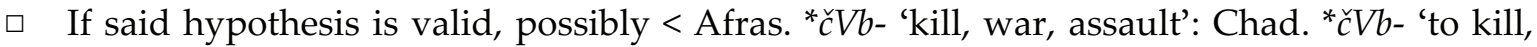
war' (compared in St. 2011 \#800 with Arb. wațbat- 'agression, attaque'): C.: Wandala čiḅa

\footnotetext{
${ }^{55}$ Eventually must be a root variant of ${ }^{*} b \mathrm{Vzr}$-, to be scored differently from the latter.

${ }^{56}$ Although this is the main Class. Arb. term for 'seed' (Kog. LE 471), it is not attested in the Qur' an as a noun.

${ }^{57}$ According to Leslau (ibid.), from Cush, which is not necessarily so in view of Sem. cognates; note especially a full coincidence with Soq. (both $<{ }^{*}$ s/šany-), which can hardly be accidental.

${ }^{58}$ Cf. also *sin- 'farm, field' (ibid. \#299, likely related): W.: Sura sèn 'Hirsefeld', Warji usina, sànána, Tsagu šinan, Kariya sôn, sîn, Siri šinàwi, Diri sàna, Paa sìna 'farm', C.: Masa síne, sénèna, Zime-Batna sīné, etc.

${ }^{59}$ Cf. Sumerian išin 'ears of corn' (Heimpel 449), 'grain-stalk' (Lieberman), isin 'stalk' (Sum. Dict. 217): an early borrowing from some Afras. (non-Semitic) language?

${ }^{60}$ Originally, hardly synonyms: rather terms denoting different seeds or various stages of seed/plant growth.
} 
'kill (many)', Malgwa čáḅa 'to kill a lot of people', Glavda čib-, Podoko čiḅe, Musgu šiba (ADB, not in St. 2011) 'kill', E.: Mubi čoḅi, Zerenkel క̌abuki 'war'; Omot. (ADB) N.: Koyra šúpe, Gimirra (Bench) ș̌up $\left(-p<{ }^{*}-b\right.$ ?) 'slaughter', Dizi šub- 'die', S.: Ongota šup/b- 'kill' (cf. tiip/b- 'die', possibly $<*$ čib-).

(2) Qur. kূd; Leb. Zåad // Class. Arb. also kậ̧idat- 'base (d'une colonne); fondations (d'un édifice)' (BK 2778 ) < Sem. * $k \varepsilon d$ 'bend, sit, put down': Syr. $k \varepsilon d$ 'bend down, kneel, prostrate' (Sok. Syr. 1388), Jib. ekęéd 'paralyze, put so. down psychologically', Soq. áḳ̂d 'take, bring down' (JM 139). ${ }^{61}$

$\square \quad$ < Afras. *kV( $k) d$ - 'bend, sit, lie down' (ADB): Egyp. (Pyr.) $k d$ 'to sleep'; (?) Chad. C.: Daba kād '(be) down', E.: Kajakse kàdi 'bas' (both possibly < *kad-, cf. St. 2011 \#81 with the comment: "Likely, loans from Arabic kāilid-at- 'base, foundation' < kִ $\hat{\varepsilon}$ 'être assis'“, which is not quite convincing because of the difference in meanings), C.: Musgu gúd (regressive voicing) 'back side', Gizey kùdú 'behind', E.: Kera gùd (regressive voicing), Mokilko kùddì-só 'buttocks' (ibid.); E. Cush.: HEC: Burji kud-ee 'behind' (compared ibid.); S. Omot.: Ongota kaada 'to lie, sleep'.

(3) Mec. žalas // Qur. žls 'to sit in Eastern fashion' (Pen. 28) < Sem. * glš 'to sit (in a special way, atop, on an elevated place)', tentatively reconstructed from identical triconsonantal roots with such different meanings as Akk. gilšu62 'hip(-bone)' (CDA 93), Hbr. glš 'to hop (alt. move down)' (HALOT 195, after Palache: basic meaning 'to jump (on one's riding animal)', Gez. galās, Tgr., Amh., Har. galas 'saddle cover' (LGz 192), Selti galas, Wol. gilas 'cloth of saddle' (LGur 275; for the meaning shift see Arb. in No. 5), Soq. galas 'montagne, cap' (LS 109; for the meaning shift see No. 4), aglīsoh 'high plain' (JM 119).

(4) Gez. nabara // also 'to stay, live, etc.', tanābara 'to be placed (one thing upon another)', ma-nbar 'seat, chair, high place, pulpit, throne' (LGz 383-4) ${ }^{63}<$ Sem. * $n b r$ 'to elevate, raise, place/sit atop': pB Hbr. (likely < Jud.), Jud. $n b r$ '(of the swine) to turn the ground up with the snout' (Ja. 870), Syr. nbr 'excitavit (terram)' (Brock. 412), Arb. nbr 'élever, exhausser (une chose); grandir, av. grandi (se dit d'un petit garçon)', mi-nbar- 'estrade, place un peu élevée au déssus du sol; chaire, prône où se place l'imam ou un khatib pour réciter la prière ou haranguer le peuple' (BK 2 1183), Amh. annäbabbärä 'heap, pile up', Arg. nabbur 'abundant, much, very, many' (LArg 215).

(5) Tna. kof bälä // < Sem. *wkp *kwp 'to bend, lie, sit': Tgr. käf belä 'sit down, sit' (LH 425), Arb. $w k f$ 'ê. incliné, penché; mettre bât sur une bête de somme', wakf- 'tapis ou peau qui l'on etend par terre pour s'y asseoir', Hrs. še-wkōf 'sleep' (JH 135), Mhr. ša-wkūf 'sleep, go to sleep, lie down', Jib. sef 'sleep' (JM 426). ${ }^{64}$

$\square \quad$ With two parallels, one of which, Cush. C.: Bilin kaf y 'to sit', isolated in Agaw, is clearly a borrowing from N. Eth. (cf., however, the remark in Appl CDA 124: "also in Ti., Tna. käf bälä"), while the other, E.: Yaaku kopchm (<*kop-ah-m-?) id., is evidently not, being either a look-alike or a remnant of the common Afras. verb, randomly spared through many millennia in an isolated language.

${ }^{61}$ Likely with a secondary - - -: cf. Akk. kadādu 'bow down' (CDA 282), Hbr. ḳdd, kww 'bow, kneel down' (HALOT 1065). See Mil. RE 97.

${ }^{62}$ If semantically compatible, this is probably a "real" term alongside giššu instead of a "result of the scribes' effort to render laterality" as suspected in SED I No. 90, cf. \#7 below).

${ }^{63}$ See the discussion (ibid. 384) about whether Gez. manbar is to be derived from Arb. minbar-or vice versa: both hypotheses seem superfluous, as both nouns are nicely derived from the corresponding verbs in each of the languages.

${ }^{64}$ One might ask whether Eth. *wkf 'take, accept, receive' (LGz 611-12) could not have evolved from 'bow down'. 
(6) Tna. (syn.) tä-kämmäțä,65 Amh. tä-ḳämmätä; Arg. (tä)kämmäța // < Eth. *kmț 'bind, hold tightly; rest, sit' (LGz 433):66 Gez. kammața 'hold tightly, bind sheaves, bend' (also takammața 'sit down, remain', acc. to Leslau, < Amh.), Har. akämäța 'rest on a base' (ibid.), cognate with Arb. $k m t$ ' 'lier avec la corde tous les quatre pieds à la fois; emmailotter un enfant au berceau; cohabiter avec une femme, etc.' (BK 2 813).

(7) Tgr. gasuy hälla // The only etymology I can suggest is < Sem. * giŝŝ- 'torso, body, side of body' (cf. SED I No. 92), including Akk. giššu 'hip, flank' (CAD g 73; on its presumable variant gilšu placed in the same entry, see \#3 above) and Gur. g'išä 'back of body' (see in SED I No. 92 arguments against its qualifying by Leslau as Cushitism). If this etymology satisfies the semantic criteria, then:

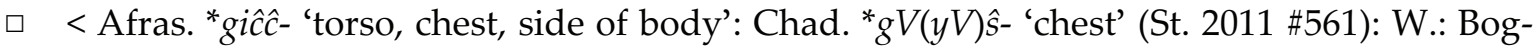
hom gyaas, Geji gyésii 'chest', isu ngeŝì 'rib', Polchi gwaŝ 'shoulder' (ADB, not in St.), Zul

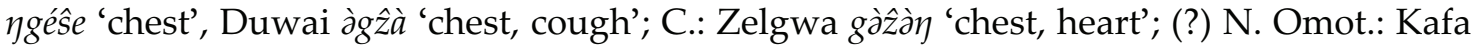
gašo 'riverbank, edge, border', Mocha gášo 'border' (suggested for comparison with Sem. in Bla. Review 502).

(8) Gaf. (tä)wannä; Sod. tonnam; Cha. čonam // Acc. to LGur III 599, from the root wni/£ with the meaning 'sit' derived in tä-stem from awäna, wanna, etc. 'place, deposit, put aside, put'. Since it is rather uncommon for the basic term to have no etymology (in this case, outside Gaf. and Gur.), I suggest that it may be related, as a variant with metathesis ( $\left.{ }^{*} w n h\right)$, to Eth. *nhy 'repose, be in peace, sleep' (LGz 394 giving no Sem. cognates outside Eth.): Gez. nəhya 'recover; repose; feel relieved; find consolation, peace; be quiet', Amh. täñ $\tilde{n}$, Arg.

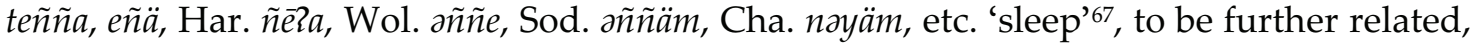
with metathesis, to Arb. hwn 'être leger, facil à faire ou endurer; se reposer, se calmer', hawn- 'repos, tranquilité; aise, facilité, aisance, commodité' (BK 2 1460-61) < Sem. *hwn 'repose, rest, be at ease': Hbr. hwn (hif) 'regard as easy' (HALOT 242), ${ }^{68}$ Thamudic hwn 'repos' (DRS 389), Sab. hwn 'soften (one's heart)' (SD 57), hyn 'ease, give ease to (?)' (ibid. 58), (?) MSA: Hrs. *hwn 'to think cheap', Soq. hawin 'better (than)' (JH 53). Cf. also DRS 388-9. Whether all these forms should be regarded as metathetic variations within one root (Sem. *wnh *nhy *hwn 'repose, rest, be at ease') or as three variant roots, is a somewhat scholastic question that requires a voluntary decision. Anyway, there are plausible parallels outside Semitic:

$\square \quad$ Egyp. (MK) hnn 'attend to, consider, trust', hnn îb 'be well-disposed to' (Faul 159; lit. 'incline one's heart (to)'? Translated as 'neigen (d. Herz)' in EG II 494: î is 'heart'); Chad. W.: Ron *n(V)yah- 'to sleep': Kulere nyà '(sich) legen, schlafen', Sha nyà, Daffo-Butura nyah 'schlafen’ (St. 2011 \# 424, ADB), C. *hwVn-: Gabin Zyenè, Kilba hány, Margi jànyi, Gudu wìyènù, Fali-Kilba wunyi 'sleep' (n.), Glavda xan, Daba wan 'to sleep', E. *wVHVn-: Kwang wé 'to sleep', Migama wáànò 'to dream' (ADB); N. Cush.: Beja nay 'sleep, rest' (LGz 304; < Eth.?).

(9) Har. (tä)gēbü(la); Wol. (tä-)gÖbälä // Probably < Eth.-Arb. ${ }^{*} g V b(b)$ - (with the auxiliary verb ala incorporated into the stem, cf. Zway (tä)gūb 'sit down, ride' and Amh. $g^{w}$ abbalä 'sit down', (tä) gwäbbälä 'sit down' LGur 256): Arb. 弓̌bb 'se jeter la face contre terre, se pros-

${ }^{65}$ The meaning 'sit' in Tna has been obtained from native speakers (glossed as 'rest on a base' in LGz 433).

${ }^{66}$ The Eth. verbs are related by Leslau to Akk. kamāṣu 'bend the knee, kneel down, squad', pB Hbr. kamșūṣ 'bent up' and Ugr. kmș 'to curl up, bend', all < Sem. *kmș (to which Jib. koọs '(snake, etc.) to curl up', kótmaṣ '(animal) to curl os. up' JJ 146 should be added), which can be compared with *kmt only as a variant root.

${ }^{67}$ Speculatively, Ugr. nhmmt 'drowsiness, fainting fit' or 'deep sleep (of death)' (<nhm + mt DUL 626) could also be related as $n h m$, with the fossilized suffix $-m-$.

${ }^{68}$ Perhaps also hōn 'wealth, property', with a possible semantic shift, but much more dubious in the case of Arm. terms meaning 'ability, means, reason, mind', quoted in HALOT 242 and DRS 388-9 as unproblematic cognates. 
terner en appuyant les mains contre la terre (en priant Dieu); tenir ses joues appuyées sur ses mains en restant debout' (BK 1 251).

$\square \quad$ With a different interpretation, perhaps, from highly hypothetic Afras. ${ }^{*} g V b b$-Vr/l- 'sit, prostrate oneself; a (sacred?) seat' (ADB): Eg. $\underline{d} b$ ? (< ${ }^{*} g b r / l$ ?) 'k. of altar, temple seat made of granit; a throne socle?'; E. Cush.: LEC: Somali (Benadir) gämbär 'round small chair with four legs'; N. Omot.: Kafa gab(b)ir-ō, Anfillo gabbero 'seat'.

(10) Hrs. ŝhewolōl; Mhr. ŝhawalūl // Also 'stay, live' in Hrs. (JH 123) and 'stay, stay where one is' in Mhr. (JM 390). A real challenge for the etymologist: no parallels either in other MSA or other Sem., the only one, irreproachable phonetically but purely conjectural semantically, being Arb. šhl III 'traire (une chamelle)' (BK 1 1202), perhaps implying the nomads' stopover for milking she-camels.

(11) Jib. skof // No parallels in other MSA. The only possible etymology is Sem. * (2a-)skup(p)'threshold': Akk. (OB on) askuppu (and, with metathesis, OA aksuppu), 'stone slab, threshold, doorsill, lower edge, step (of a wagon)' (CAD $a_{2} 333$ ), (OB on) askuppatu 'slab, threshold, door-sill' (ibid. 334), Hbr. maškōp 'lintel, doorstep' (HALOT 652, hapax), šākäp 'doorjamb, door support' or 'a space in a wall for a door or for a window' (HALOT 1646-7, hapax), škp (nif) 'to look down from above' (ibid. 1645), pB. Riskuppā 'threshold, lintel, lower door-sill' (Ja 97; from or influenced by Jud.), Arm.: Hatra 2skp 'threshold' (HJ 86), Syr. Zeskūpat- 'limen; rupes' (Brock. 35), Jud. Ziskūpt- 'door-sill' (Ja. 94), Ziskūpt- 'threshold, lintel, lower door-sill' (ibid. 97), Sab. $s_{1} \mathrm{kf}$ 'roof, roofing, ceiling, floor (of multi-storied building)' and 'to roof (a building)' (SD 127-8), Arb. 2uskuffat- 'the threshhold of a door, upon which one treads', sākif- 'the lintel of a door, the upper and lower extremity of the door' (Lane 1391), sakf- 'ceiling, roof, or covering' (ibid. 1383). An entangled case of what seems a chain of borrowings (Akk. askuppu > Arm. > Hbr. and Arb.?) and contamination of two unrelated (or variant?) roots: ${ }^{*} s k p$ forms the terms for 'threshold' and ${ }^{*} s k p$ forms the terms for 'roof, ceiling, etc.' Anyway, Jib. skəf neatly fits in with Sem. *skp, suggesting that the primary meaning of the Jib. verb was 'to sit on a threshold, in the door/gate'.

(12) Soq. ízem // Also 'rester' (LS 155 with no Sem. parallels). There are several highly hypothetical etymological options. One is to suppose for the Soq. verb the original meaning 'sit at the head or at the helm', later generalized as simply 'sit': cf. Mhr. zasim 'head of a family' (JM 463), Jib. zSim 'the most important person in, head of the family' (JJ 314, tentatively comparing it with Soq. áz\{am 'sit' and what is quoted ibid. as mózZhim 'majlis', not in LS), Arb. zaßim'chef, prince, représentant d'une communauté, agent plénipotentiaire qui parle au nom d'elle', likely from or contaminated with $z$ \{m 'parler, dire' (both BK 1 992), related to Hbr. $z$ \&m 'curse', Syr. z⿰m 'scold' (HALOT 276) and Sab. z⿰m 'declaration' (SD 170; cf. DRS 770). Another option is comparison with Jib. z⿰氵工千t 'buggalow, kind of ship', Arb. zasāaim- (pl.), Tgr. zasimät 'bateau, barque' (the Jib. and Tgr. terms are likely Arabisms; all three are quoted in DRS 770, without raising the borrowing issue) that implies the original meaning 'sit in a boat' for the Soq. verb. A third option is to compare it with Arb. $z$ Im III 'serrer quelqu'un dans la foule' (BK 1 992, cf. a variant root $z \mathrm{hm}$ III), in which case the original meaning in Soq. should have been 'to sit crowded together, sit squashed up'. With none of the three options convincing enough, there are, however, direct external parallels meaning 'to sit' in Chad. ${ }^{69}$

$\square \quad$ Chad. W.: Hausa zámáa 'be, become, happen, keep on doing, sitting, settling room', Sura zum 'stoop, bend down', Bolewa zuum, 亏̌uum, Ngamo క̌oom 'to squat' (note the hiatus in

${ }^{69}$ Somewhat compromised, as in many other cases, by the hugeness of the cumulative Chadic lexica, which considerably increases the probability of chance resemblance (reminding of a similar problem with Arabic), and by the low representativeness of Chadic lexemes brought to comparison vs. the great number of Chadic languages. 
the latter forms, probably pointing to a lost laryngeal: cf. -£- in Soq.), C.: Gude žàmú 'sitting on smth. to press down', Ouldem zàm fàr 'to incline' (jàr 'head'), Masa zàm 'wait' (adduced as two different entries in St. 2011 \#478 and 479).

$\diamond \quad$ Mlt. poža likely < Italian (ap)poggiare.

$\rightarrow$ Common North and West Semitic. * wtb (\#1).

\section{Literature}

ADB - Afrasian Data Base (http://starling.rinet.ru and http://ehl.santafe.edu).

AHw - SODEN, W. von., 1965-1981. Akkadisches Handwörterbuch. Wiesbaden.

App CDA - Appleyard, D., A., 2006. A Comparative Dictionary of the Agaw Languages. Kuschitische Sprachstudien / Cushitic Language Studies, Band 24. Köln.

Baet. - BAETEMAN, J., 1929. Dictionnaire amarigna - français suivi d'un vocabulaire français - amarigna. Dire-Daoua. BK - BibERSTEIN-KAZIMIRSKI, A. de., 1860. Dictionnaire arabe-français. Paris.

Bla. Om. - BlAŽEK, V., 2008. Lexicostatistical comparison of Omotic languages. In: In Hot Pursuit of Language in Prehistory. Ed. by John D. Bengtson. Amsterdam-Philadelphia, 57-148.

Bla. Review - BlAŽEK, V., 2001. Semitic Etymological Dictionary I. Review Article. Archive Orientální. Vol. 69. Praha, p. 495-510.

Blachère - Blachère, R., M. CHOuÉMI \& C. DenizeAu, 1964-. Dictionnaire arabe-français-anglais. Paris: Maisonneuve and Larose.

Bnd. Om. - Bender, M.L., 2003. Omotic lexicon and Phonology. Carbondale.

Brock. - BRockelmanN, C., 1928. Lexicon Syriacum. Halle.

Bulakh Akk. - BUlAKH, M., 2003. Etymological Notes on the Akkadian Colour Terms. Studia Semitica (FS A. Militarev). Moscow, 3-17.

Bulakh Dis. - BULAKн, M., 2005. Цветообозначение семитских языков в этимологическом аспекте (Color потіпатіоп in Semitic in the etymological aspect). Doctorate dissertation. Russian State University in the Humanities, Moscow.

Bulakh Gez. - BulaKH, M., 2006. Basic Color Terms in GeYez: Synchronic and Diachronic Aspects. Proceedings of the XVth International Conference of Ethiopian Studies. Hamburg July 20-25, 2003. Wiesbaden, 737-745.

Bulakh Hbr. - BulaKH, M., 2006. Basic Color Terms of Biblical Hebrew in Diachronic Aspect. Babel and Bibel: Annual of Ancient Near East, Old Testament and Semitic Studies, No. 3. Winona Lake, Indiana, p. 182- 216.

CAD - OppenheIm, L., E. ReIner \& M.T. Roth (ed.), 1956-. The Assyrian Dictionary of the Oriental Institute, the University of Chicago. Chicago.

CDA - A Concise Dictionary of Akkadian, 2000, ed. by BlACK J., A. GEORGE and N. POstGATE. Wiesbaden.

DM - Drower, E.S. \& R. MACUCH, 1963. A Mandaic Dictionary. Oxford.

DRS - COHEN, D., 1970-. Dictionnaire des racines sémitiques ou attestées dans les langues sémitiques. La Haye.

DUL - Olmo Lete, G. \& J. SAnmartín, 2003. A Dictionary of the Ugaritic Language in the Alphabetic Tradition. Leiden-Boston.

EDE I - TAKÁCS, G., 1999. Etymological Dictionary of Egyptian, Volume One: A Phonological Introduction. LeidenBoston- Köln.

EDE II - TAKÁCS, G., 2001. Etymological Dictionary of Egyptian, Volume Two: $b$-, $p$-, $f$-. Leiden-Boston-Köln.

EDE III - TAKÁCS, G., 2008, Etymological Dictionary of Egyptian, Volume Three: m-. Leiden-Boston.

EG - ERMAN, A. \& H. GRAPOW, 1957-71. Wörterbuch der aegyptischen Sprache, I-VII. Berlin.

Gr. - GRAGG, G.. 1982. Oromo Dictionary. East Lansing.

HAlOT - KoeHler, L. \& W. Baumgartner, 1994-1996, 1999-2000. The Hebrew and Aramaic Lexicon of the Old Testament I-III. Leiden, New York \& Köln. IV-V. Leiden, Boston \& Köln.

Heimpel - HeIMPEL, W., 1968. Tierbilder in der sumerischen Literatur. Rome.

HJ - HoftiJzer, J. and K. Jongeling, 1995. Dictionary of the North-West Semitic Inscriptions. Leiden-New YorkKöln.

HRSC - EHRET, C., 1980. The Historical Reconstruction of Southern Cushitic Phonology and Vocabulary. Berlin.

HSED - OREL, V. and O. STOLBOVA. 1995. Hamito-Semitic Etymological Dictionary. Materials for a Reconstruction. Leiden-New York-Köln. 
Ja. - JASTROW, M., 1996. A Dictionary of the Targumim, the Talmud Babli and Yerushalmi, and the Midrashic Literature. New York.

Jg. Bid. - Jungraithmayr, H. and Alio, K. Lexique bidiya. Frankfurt. 1989.

JH - Johnstone, T. M., 1977. Harsūsi Lexicon. New York - Toronto.

JJ - Johnstone, T. M., 1981. Jibbāli Lexicon. New York (NY).

JM - Johnstone, T. M., 1987. Mehri Lexicon. London.

Kane A - Kane, T. L., 1990. Amharic-English Dictionary. Wiesbaden.

Kane T - KANE, T. L., 2000. Tigrinya-English Dictionary. Vol. I-II. Springfield.

Kog. Eth. - KogAN, L., 2005. Common Origin of Ethiopian Semitic: the Lexical Dimension. Scrinium. T. 1: Varia Aethiopica. In Memory of Sevir B. Chernetsov (1943-2005).

Kog. LE - KogAn, L., 2006. Lexical evidence and the genealogical postion of Ugaritic (I). Babel and Bibel: Annual of Ancient Near East, Old Testament and Semitic Studies, No. 3. Winona Lake, Indiana, p. 429-488.

Kogan MS - KoGAN, L., 100-wordlist of Soqotri (manuscript).

Kog. Ug.-Can. - KogAn, L., 2010. Genealogical Position of Ugaritic: the Lexical Dimension Lexical Isoglosses Between Ugaritic and Canaanite. Sefarad, vol. 70:1, enero-junio 2010, p. 7-50.

Kog. Ug.-Sem. - KogAN, L., 2010. Genealogical Position of Ugaritic: the Lexical Dimension. Lexical Isoglosses between Ugaritic and other Semitic Languages. Sefarad, vol. 70:2, julio-septiembre 2010, p. 2-51.

Lane - LANE, E. W., 1867. Arabic-English Lexicon. London.

LArg - LesLaU, W., 1997. Ethiopic Documents: Argobba. Wiesbaden.

LGaf - LESLAU, W., 1956. Étude descriptive et comparative du Gafat (Éthiopien méridional). Paris.

LGur - LesLaU, W., 1979. Etymological Dictionary of Gurage (Ethiopic). Vol. III. Wiesbaden.

LGz - Leslau, W., 1987. Comparative Dictionary of Geez (Classical Ethiopic). Wiesbaden.

LH - LiTTMANN, E. and M. Höfner, 1956. Wörterbuch der Tigre-Sprache. Tigre-deutsch-englisch. Wiesbaden.

LHar - LeSLAU, W., 1963. Etymological Dictionary of Harari. Berkeley and Los Angeles.

Lieberman - LieberMAN, S., 1977 - S. Lieberman. Sumerian Loanwords in Old Babylonian Akkadian. Missoula.

LLw - LesLaU, W., 1990. Arabic Loanwords in Ethiopian Semitic. Wiesbaden.

LM - ARbACH, M., 1993. Le madābien: lexique, onomastique et grammaire d'une langue de l'Arabie méridionale préislamique. T. 1: Lexique madāäbien. Aix-en-Provence.

LS - LeSLAU, W., 1938. Lexique Soqoțri (Sudarabique moderne) avec comparaisons et explications étymologiques. Paris.

Maizel - MAIZEL, S., 1983. Puti razvitija kornevogo fonda semitskih jazykov. Moscow.

Mil. Farm. - MilitareV, A., 2002. The Prehistory of a Dispersal: the Proto-Afrasian (Afroasiatic) Farming Lexicon. Examining the Farming/Language Dispersal Hypothesis, eds. P. BellWoOD \& C. RENFreW. McDonald Institute Monographs. Cambridge, 135-50.

Mil. RE - Militarev, A., 2005. Root extension and root formation in Semitic and Afrasian. Proceedings of the Barcelona Symposium on comparative Semitic, 19-20/11/2004, Aula Orientalis 23/1-2, p. 83-130.

Mil. SE - MilitareV, A., 2010. The Significance of etymology for the interpretation of ancient writings: from the Hebrew Bible to the New Testament. Appendix 2. In: Militarev, A., The Jewish Conundrum in World History. Academic Studies Press. Boston, p. 258-261.

Mil. 2000 - MilitAREV, A., 2000. Towards the chronology of Afrasian (Afroasiatic) and its daughter families. Time Depth in Historical Linguistics. Volume 1. Ed. by C. RENFrew, A. MCMAHON \& L. TrASK. The McDonald Institute for Archaeological Research. Cambridge, 267-307.

Mil. 2004 - Militarev, A., 2004. Another Step towards the Chronology of Afrasian (I). Orientalia et Classica. Papers of the Institute of Oriental and Classical Studies. Issue V. Babel and Bibel 1. Ancient Near East, Old Testament and Semitic Studies. Moscow, 282-333.

Mil. 2007 - Militarev, A., 2007. Toward a Complete Etymology-Based Hundred Word List of Semitic. Irems 1-34 (First Third). Proceedings of the $7^{\text {th }}$ International Semito-Hamitic Congress (Berlin, Sept.13-15, 2004). Aachen, p. 71-102.

Mil. 2008 - MilitareV, A., 2008. Toward a Complete Etymology-based One Hundred Wordlist of Semitic: Items 34-66 (Second Third). FS H. Jungraithmayr and A. Dolgopolsky. Ed. by G. TAKACS, p. 194-222.

Mil. 2010 - MilitareV, A., 2010. A complete etymology-based hundred wordlist of Semitic updated: Items 1-34. Journal of Language Relationship, № 2, 2010, p. 43-78.

Mil. 2011 - MilitareV, A., 2011. A complete etymology-based hundred wordlist of Semitic updated: Items 35-54. Journal of Language Relationship, № 5, 2011, p. 69-95. 
MQK - MOUS, M., M. QORRO and R. KIESSLING, 2002. Iraqw-English Dictionary. Köln: Rüdiger Köppe Verlag.

Nak. - NAKANO, A. 1986. Comparative Vocabulary of Southern Arabic. Tokyo.

ND - DOLGOPOLSKY, A. Nostratic Dictionary (manuscript).

N-Z - Nait-Zerrat, K. Dictionnaire des racines berbères. Paris-Louvain. 1998-.

Pen. - Penrice, J., 1873. A Dictionary and Glossary of the Koran. London.

PH - Parker, E. M. and R. J. HAYWARD, 1985. An Afar-English-French Dictionary (with Grammatical Notes in English). London.

RAf - REINISCH, L., 1886. Die SAfar-Sprache. Wien.

Ricks - RICKS, S. D., 1989. Lexicon of Inscriptional Qatabanian. Roma.

SAM 1978 - HeINE, B. The Sam Languages: a history of Rendille, Boni and Somali. Afroasiatic Linguistics 6/2 (1978), 23-116.

Sarg. - САРгис (архимандрит), 1909. Русско-сирский лексиконъ. Урмия. (SARGIS, archimandrite, 1909. RussianSyriac Lexicon. Urmia.)

Sat. - SAtterthweit, A. C., 1960. Rate of Morphemic Decay in Meccan Arabic. International Journal of American Linguistics. 26/3, 254-261.

SD - Beeston, A. F. L., M. A. Ghul, W. W. Muller \& J. RyCKMAns, 1982. Sabaic Dictionary (English-French-Arabic). Louvain-la-Neuve.

SED I - Militarev, A. \& L. Kogan, 2000. Semitic Etymogical Dictionary. vol. I: Anatomy of Man and Animals. Münster. SED II - MilitareV, A. \& L. KogAn, 2005. Semitic Etymogical Dictionary. Vol. II: Animal Names. Münster.

Sok. JP - SOKOlOFF, M., 1990. A Dictionary of Jewish Palestinian Aramaic. Jerusalem.

Sok. Syr. - SoKOloff, M., 2009. A Syriac Lexicon. Winona Lake, Indiana - Piscataway, New Jersey.

SSL - SimeOne-Senelle, M.C. and LonNet, A., 1985-86. Lexique des noms des parties du corps dans les langues sudarabiques modernes. Première partie: la tête. Matériaux Arabes et Sudarabiques, 3, 259-304.

Star. - StAROSTIN, S., 2000. Comparative-historical linguistics and lexicostatistics, in Time Depth in Historical Linguistics, vol. 1, eds. C. RenfreW, A. MCMAHON \& L. Trask. (Papers in the Prehistory of Languages.) Cambridge: The McDonald Institute for Archaeological Research, 223-265.

St. 2005 - Stolbova, O., 2005. Chadic lexical database. Issue I ( $L, N, N y, R)$. Kaluga.

St. 2007 - Stolbova, O., 2007. Chadic lexical database. Issue II (lateral fricatives). Moscow-Kaluga.

St. 2009 - Stolbova, O., 2009. Chadic lexical database. Issue III (sibilants and sibilant affricates). Moscow.

St. 2011 - Stolbova, O., 2011. Chadic lexical database. Issue I (velars). Moscow.

Sum. Dict. - The Sumerian Dictionary of the University of Pennsylvania Museum. Ed. A. W. SJOBERG. Vol. I: A. Pt. III. Philadelphia, 1998.

Sw. 1952 - SwADESH, M., 1952. Lexicostatistical dating of prehistoric ethnic contacts: With special reference to North American Indians and Eskimos. Proceedings of the American Philosophical Society 96, 452-463.

Sw. 1955 - SwADESH, M., 1955. Toward greater accuracy in lexicostatistical dating. International Journal of American Linguistics 21, 121-137.

Tak. 2001 - TAKACS, G., 2001. Towards Proto-Afro-Asiatic Phonology: Ancient Remnants in South Cushitic, Angas-Sura, and North Bauchi. Rocznik Orientalistyczny 54/2, 55-125.

Tomb. - Tомваск, R. S., 1978. A Comparative Semitic Lexicon of the Phoenician and Punic Languages. Ann Arbor.

Tser. - ЦЕРЕТЕЛИ, К. Г., 1958. Хрестоматия современного ассирийского языка со словарем. Тбилиси. (ТSЕRETELI, K. G., 1958. A Neo-Assyrian Anthology (with glossary). Tbilisi).

Vyc. - VycichL, W., 1983. Dictionnaire étymologique de la langue copte. Leuven.

Статья является третьей частью этимологического разбора, проделанного автором для стословного списка Сводеша по семитским языкам (первые две части были уже опубликованы в третьем и пятом номерах «Вопросов языкового родства»). Анализу подвергаются очередные двадцать элементов списка, для каждого из которых предлагается прасемитская реконструкция и обсуждаются возможные параллели в других языках афразийской макросемьи.

Ключевые слова: семитские языки, афразийские языки, этимология, глоттохронология, лексикостатистика. 
